Atmos. Chem. Phys., 13, 3587-3601, 2013

www.atmos-chem-phys.net/13/3587/2013/

doi:10.5194/acp-13-3587-2013

(c) Author(s) 2013. CC Attribution 3.0 License.

\title{
Modeling of daytime HONO vertical gradients during SHARP 2009
}

\author{
K. W. Wong ${ }^{1, *}$, C. Tsai ${ }^{1}$, B. Lefer ${ }^{2}$, N. Grossberg ${ }^{2}$, and J. Stutz ${ }^{1}$ \\ ${ }^{1}$ Department of Atmospheric and Oceanic Sciences, University of California Los Angeles, Los Angeles, CA 90095, USA \\ ${ }^{2}$ Department of Earth and Atmospheric Science, University of Houston, Houston, TX 77204-5007, USA \\ *now at: Jet Propulsion Laboratory, California Institute of Technology, Pasadena, CA 91109, USA
}

Correspondence to: J. Stutz (jochen@atmos.ucla.edu)

Received: 11 September 2012 - Published in Atmos. Chem. Phys. Discuss.: 23 October 2012

Revised: 7 March 2013 - Accepted: 8 March 2013 - Published: 2 April 2013

\begin{abstract}
Nitrous acid (HONO) acts as a major precursor of the hydroxyl radical $(\mathrm{OH})$ in the urban atmospheric boundary layer in the morning and throughout the day. Despite its importance, HONO formation mechanisms are not yet completely understood. It is generally accepted that conversion of $\mathrm{NO}_{2}$ on surfaces in the presence of water is responsible for the formation of HONO in the nocturnal boundary layer, although the type of surface on which the mechanism occurs is still under debate. Recent observations of higher than expected daytime HONO concentrations in both urban and rural areas indicate the presence of unknown daytime HONO source(s). Various formation pathways in the gas phase, and on aerosol and ground surfaces have been proposed to explain the presence of daytime HONO. However, it is unclear which mechanism dominates and, in the cases of heterogeneous mechanisms, on which surfaces they occur.

Vertical concentration profiles of HONO and its precursors can help in identifying the dominant HONO formation pathways. In this study, daytime $\mathrm{HONO}$ and $\mathrm{NO}_{2}$ vertical profiles, measured in three different height intervals (20-70, 70-130, and 130-300 m) in Houston, TX, during the 2009 Study of Houston Atmospheric Radical Precursors (SHARP) are analyzed using a one-dimensional (1-D) chemistry and transport model. Model results with various HONO formation pathways suggested in the literature are compared to the the daytime $\mathrm{HONO}$ and $\mathrm{HONO} / \mathrm{NO}_{2}$ ratios observed during SHARP. The best agreement of $\mathrm{HONO}$ and $\mathrm{HONO} / \mathrm{NO}_{2}$ ratios between model and observations is achieved by including both a photolytic source of HONO at the ground and on the aerosol. Model sensitivity studies show that the observed diurnal variations of the $\mathrm{HONO} / \mathrm{NO}_{2}$ ratio are not reproduced by the model if there is only a photolytic $\mathrm{HONO}$ source on aerosol or in the gas phase from $\mathrm{NO}_{2}^{*}+\mathrm{H}_{2} \mathrm{O}$. Fur-
\end{abstract}

ther analysis of the formation and loss pathways of HONO shows a vertical dependence of HONO chemistry during the day. Photolytic HONO formation at the ground is the major formation pathway in the lowest $20 \mathrm{~m}$, while a combination of gas-phase, photolytic formation on aerosol, and vertical transport is responsible for daytime HONO between 200$300 \mathrm{~m}$ a.g.l. HONO removal is dominated by vertical transport below $20 \mathrm{~m}$ and photolysis between $200-300 \mathrm{~m}$ a.g.l.

\section{Introduction}

Early observations of nitrous acid (HONO) in the polluted urban atmosphere were made by differential optical absorption spectroscopy (DOAS) by Platt et al. (1980), who pointed out its role as a hydroxyl radical $(\mathrm{OH})$ precursor in the morning. It has since been recognized that HONO photolysis (Reaction R1) plays an important role in initiating daytime photochemistry.

$\mathrm{HONO}+h v \stackrel{\lambda<400 \mathrm{~nm}}{\longrightarrow} \mathrm{OH}+\mathrm{NO}$

During the day, HONO has long been expected to reach a pseudo steady state between its photolysis (Reaction R1), gas-phase reaction with $\mathrm{OH}$ (Reaction R2), and gas-phase formation from $\mathrm{NO}$ and $\mathrm{OH}$ (Reaction R3). The theoretical pseudo steady-state HONO mixing ratio is in the low ppt (for the remainder of the manuscript we will use ppt as the equivalent of pmol mol${ }^{-1}$ ) levels in most areas (Kleffmann, 2007).

$\mathrm{HONO}+\mathrm{OH} \longrightarrow \mathrm{NO}_{2}+\mathrm{H}_{2} \mathrm{O}$

$\mathrm{NO}+\mathrm{OH} \longrightarrow \mathrm{HONO}$ 
However, recent field observations show that daytime HONO concentrations can be substantially higher than the theoretical steady-state mixing ratio, reaching up to a few hundred ppt in urban and rural areas (Kleffmann et al., 2005; Acker et al., 2006a; Zhou et al., 2007; Wong et al., 2012). These elevated daytime HONO mixing ratios indicate the presence of unknown HONO formation mechanisms, which make $\mathrm{HONO}$ also a significant $\mathrm{OH}$ precursor throughout the day. Various studies show that up to $55 \%$ of the total $\mathrm{OH}$ budget during the day can be attributed to HONO photolysis in the morning and throughout the day (Mao et al., 2010; Elshorbany et al., 2009; Acker et al., 2006b; Kleffmann et al., 2005; Aumont et al., 2003). The formation rate of daytime HONO by unknown pathways has been estimated in rural and urban regions in the range of $1-35 \times 10^{6} \mathrm{molec} \mathrm{cm}^{-3} \mathrm{~s}^{-1}$ (Acker et al., 2006a; Zhang et al., 2009; Elshorbany et al., 2009; Kleffmann et al., 2005; Zhou et al., 2002; Su et al., 2008; Sörgel et al., 2011a; Ren et al., 2010).

Based on recent laboratory and field experiments various photolytic formation pathways occurring in the gas phase and on aerosol/ground surfaces have been proposed to explain the observed daytime HONO levels ( $\mathrm{Li}$ et al., 2008; Stemmler et al., 2006; George et al., 2005; Zhou et al., 2007; Kleffmann, 2007). Potential daytime gas-phase formation pathways of $\mathrm{HONO}$ include the reaction of photoexcited $\mathrm{NO}_{2}$, $\mathrm{NO}_{2}^{*}$, with water vapor, as proposed by Li et al. (2008), and photolysis of ortho-nitrophenols, as proposed by Bejan et al. (2006). Heterogeneous $\mathrm{NO}_{2}$ to $\mathrm{HONO}$ conversion was proposed to be enhanced by solar irradiance on some types of surfaces. These surfaces include those coated with phenols and aromatic ketones as proposed by George et al. (2005) and humic acids and soil as suggested by Stemmler et al. (2006, 2007). Another proposed daytime HONO formation mechanism is the photolysis of surface adsorbed nitric acid $\left(\mathrm{HNO}_{3}\right.$ ) (Zhou et al., 2007; He et al., 2006; Beine et al., 2002; Dibb et al., 2002; Zhou et al., 2002, 2003, 2011). Both of these heterogeneous formation pathways, $\mathrm{NO}_{2}$ conversion and photolysis of $\mathrm{HNO}_{3}$, can potentially occur on aerosol and ground surfaces. Recently, Su et al. (2011) also proposed the release of soil nitrite as a possible HONO source.

The study of HONO sources is challenging as it requires the separation of processes occurring in the gas phase, the aerosol, and on ground surfaces. Observations of the vertical distribution of $\mathrm{HONO}$ and its precursors in the daytime boundary layer can carry important information on the sources and formation of HONO. For instance, a strong continuous ground source of HONO would lead to higher concentrations near the ground, while formation on aerosol surfaces should lead to a relatively uniform HONO vertical boundary layer distribution, assuming the most likely case, that the aerosol profile is uniform in the daytime boundary layer. Similarly, gas-phase sources in a well-mixed boundary layer should also, in principle, lead to a fairly uniform HONO vertical distribution. However, only a few observational studies have been performed to measure daytime HONO verti- cal profiles (Kleffmann, 2007; Zhang et al., 2009; Villena et al., 2011; Zhou et al., 2001; Häseler et al., 2009). The results from these studies are not conclusive. Kleffmann (2007) did not observe significant vertical HONO gradients in the lowest $190 \mathrm{~m}$ of the atmosphere in a semi-rural area in Germany. Similarly, Sörgel et al. (2011b) did not observe gradients in the lowest $25 \mathrm{~m}$ of a forest. In contrast, Villena et al. (2011) found elevated levels of HONO at $6 \mathrm{~m}$ compared to $53 \mathrm{~m}$ altitude in a polluted urban area. Two aircraft observations have been reported. Zhang et al. (2009) reported negative concentration profiles up to $2500 \mathrm{~m}$ altitude, while Häseler et al. (2009) observed no gradients in the lowest $1000 \mathrm{~m}$ of the atmosphere. Flux measurements of HONO have been carried out to study the daytime sources of HONO. Zhou et al. (2011) reported HONO fluxes in a forest canopy, with a peak flux at noon of $1 \times 10^{10} \mathrm{molec}^{-2} \mathrm{~s}^{-1}$. Another study by the same group measured HONO flux over arctic snow and reported maximum HONO fluxes of $1 \times 10^{9} \mathrm{molec}^{-2} \mathrm{~s}^{-1}$. Ren et al. (2011) reported HONO fluxes of up to $6 \times 10^{9}$ molec $\mathrm{cm}^{-2} \mathrm{~s}^{-1}$ in Bakersfield, CA, and a strong correlation of the flux with $\mathrm{NO}_{2}$ and solar radiation, while the fluxes over a forest were close to zero.

In addition to observations of vertical profiles, atmospheric chemistry and transport models are often necessary to test and validate the potential HONO formation mechanism. So far, there have been very limited modeling studies on daytime HONO focusing on vertical gradients. Vogel et al. (2003) used a 1-D chemistry and transport model to reproduce tower measurements of daytime HONO vertical gradients in Germany (Kleffmann, 2007). Their model, which took into account HONO emissions, gas-phase formation and heterogeneous formation, underestimated daytime HONO concentrations by $30-50 \%$. Inclusion of a photolytic HONO source, which was proportional to the $\mathrm{NO}_{2}$ photolysis frequency, lead to much better agreement between the modeled and the observed HONO concentrations. Aumont et al. (2003) used a two layer box-model to study the contribution of $\mathrm{HONO}$ photolysis to the $\mathrm{OH}$ budget, but no observation of HONO was available to validate the HONO simulations. Their study showed that when HONO emission, gas-phase reaction and heterogeneous formation on ground and aerosol were considered in the model, daytime HONO was a significant source of $\mathrm{OH}$ in wintertime conditions. A few 3-D model studies on HONO have been published recently (Czader et al., 2012; Gonçalves et al., 2012; Sarwar et al., 2008, 2009). Most of these studies did not analyze the vertical distribution of HONO in detail. Only Czader et al. (2012) showed a comparison of LP-DOAS (long-path differential optical absorption spectroscopy instrument) profile data with their model. They also concluded that a surface formation mechanism was necessary to improve HONO levels simulated by the model.

Following the idea that vertical profiles of HONO provide important information on its formation mechanisms, continuous daytime vertical profiles of $\mathrm{HONO}$ and $\mathrm{NO}_{2}$ mixing 
ratios were measured at three altitude intervals in Houston, TX, in spring 2009. Analysis of the observational data of $\mathrm{HONO}, \mathrm{NO}_{2}$ and $\mathrm{HONO} / \mathrm{NO}_{2}$ ratios showed the presence of a photolytic $\mathrm{HONO}$ source, which exhibited a dependence on $\mathrm{NO}_{2}$ concentrations and solar irradiance. The conversion of $\mathrm{NO}_{2}$ to $\mathrm{HONO}$ was most likely occurring on the ground, rather than on aerosol or in the gas-phase (Wong et al., 2012). Here we will further expand this analysis by using a 1-D atmospheric chemistry and transport model to understand the observed vertical profiles of $\mathrm{HONO}, \mathrm{NO}_{2}$ and $\mathrm{HONO} / \mathrm{NO}_{2}$ ratios in Houston, TX. Model runs that include parameterizations of the various proposed HONO formation mechanisms are compared to the field observations to identify the dominant processes. The altitude dependence of daytime HONO chemistry will also be investigated.

\section{Approach}

\subsection{Experimental}

Daytime $\mathrm{HONO}$ and $\mathrm{NO}_{2}$ vertical mixing ratio profiles were measured from 20 April to 30 May during the 2009 Study of Houston Atmospheric Radical Precursors (SHARP), in Houston, TX, using UCLA's (University of California Los Angeles) long-path differential optical absorption spectroscopy instrument. The LP-DOAS instrument was set up on the roof of the North Moody Tower on the campus of the University of Houston, at an altitude of about $70 \mathrm{~m}$ above the ground. The instrument sent a collimated beam of light from a Xe arc lamp onto three retroreflectors, which were mounted on the top of three buildings located in downtown Houston at distances of 4.1, 5.05, and $5.15 \mathrm{~km}$ from the Moody Tower at altitudes of 20, 130, and $300 \mathrm{~m}$ a.g.l., respectively). The LPDOAS telescope was aimed consecutively at these retroreflectors to measure the absorptions of $\mathrm{HONO}$ and $\mathrm{NO}_{2}$ between the University of Houston and downtown Houston. The retrieved mixing ratios were horizontally averaged between the Moody Tower and downtown Houston and vertically averaged over the LP-DOAS height intervals: lower (20-70 m), middle (70-130 m), and upper (130-300 m). Details of the experiment and data analysis are described in Wong et al. (2012) and references therein. Our analysis will focus on the same sunny days as outlined in Wong et al. (2012): 21 April, 17 and 18 May. These days were chosen as they provided the only cloud free conditions that allow a rigorous analysis of HONO chemistry.

\subsection{Model description}

To more quantitatively understand the observations of HONO vertical profiles, which are the results of a combination of chemistry and vertical mixing, we employ a 1-D chemistry and transport model. The purpose of the model is to help distinguish between the different formation processes outlined above and to help understand how HONO chemistry changes with altitude, rather than to model the entire boundary layer chemical system. We will, therefore, focus on the model output of $\mathrm{NO}_{2}, \mathrm{HONO}$ and $\mathrm{HONO} / \mathrm{NO}_{2}$ ratios.

We use RCAT8.2, a vertically highly resolved chemistry and transport model, which includes the gas-phase Regional Atmospheric Chemistry Mechanism (RACM), 84 reactive species and 244 gas-phase chemical reactions (Stockwell et al., 1997). RCAT has been successfully used to describe nocturnal HONO formation and vertical profiles (Wong et al., 2011), to investigate the impact of nocturnal processes on daytime chemistry (Wong and Stutz, 2010), and most recently to investigate the impact of $\mathrm{NO}_{3}$ photolysis from artificial light sources (Stark et al., 2011). As the model has been described in detail previously, only a short description will be given here. A detailed description of the parameterization of HONO will be given in Sect. 2.2.1.

The model subdivides the lowest $3000 \mathrm{~m}$ into 32 grid cells, including 5 grid cells with cell heights decreasing logarithmically below $1 \mathrm{~m}$ to take into account the inefficient vertical transport near the ground. Vertical exchange of trace species between adjacent boxes occurs through turbulent diffusion, as well as molecular diffusion in the lowest millimeters above the surface, as chemical reactions take place simultaneously at all altitudes. RCAT8.2 considers temporally varying anthropogenic emissions, predominately from traffic between $0.1 \mathrm{~m}$ and $1 \mathrm{~m}$ altitude, as well as biogenic emissions at the ground and between $1 \mathrm{~m}$ and $10 \mathrm{~m}$ altitude. Anthropogenic VOC (volatile organic compounds) and $\mathrm{NO}_{\mathrm{x}}$ emissions are linked in the model using emission ratios based on Kurtenbach et al. (2001, 2002). Surface uptake resulting in dry deposition and chemistry on aerosol and ground surfaces are included as well. Chemistry in the liquid phase is currently not considered in the model. Photolysis frequencies of chemical species are calculated based on Landgraf and Crutzen (1998) and are approximated by a sine function, which turns positive after the time of sunrise. Photolysis rates were compared with observations during SHARP to ensure their accuracy.

The chemistry of molecules on the ground surface, including that of $\mathrm{HONO}$ and $\mathrm{NO}_{2}$, is calculated from the number of molecules in the lowest grid cell colliding with the ground and the respective uptake coefficients (Wong and Stutz, 2010). The ground is assumed to be flat in the model and no buildings or trees are considered. The uptake rates of trace gases, including $\mathrm{HONO}$ and $\mathrm{NO}_{2}$, on aerosols are determined from the aerosol surface area density and the uptake coefficients according to the mass transfer equation given by Fuchs and Sutugin (1971) and assuming an average particle diameter of $150 \mathrm{~nm}$. The aerosol vertical profile is assumed to be uniform in the boundary layer.

Vertical transport of trace gases, $j$, is calculated based on a flux-gradient relationship of concentration of trace gas, $C$, and eddy diffusivity, $K_{z}$ (Geyer and Stutz, 2004). Eddy diffusivity is calculated by the Monin-Obukhov theory with the Von Kármán constant $\kappa$, the friction velocity $u^{*}$ and the stability correction factor $\Phi$, which is a function of altitude 
and stability through the Obukhov length $L$ (Businger et al., 1971; Stull, 1988).

$j(z, t)=-K_{z}(z, t) \cdot \frac{\partial C(z, t)}{\partial z}$ where $K_{z}(z, t)=\frac{\kappa \cdot u^{*}(t) \cdot z}{\Phi\left(\frac{z}{L}, t\right)}$

As the purpose of the model for this study is solely the investigation of $\mathrm{HONO}$ chemistry, we use observations of $\mathrm{NO}_{2}$ vertical profiles to constrain $\mathrm{NO}_{\mathrm{x}}$ emissions and vertical mixing. This comparison is achieved by averaging the model results over the LP-DOAS height intervals. The results of this comparison will be discussed below.

\subsubsection{Parameterization of HONO chemistry}

We started our analysis using the RCAT8.2 version, which was previously used for modeling of nocturnal HONO (Wong et al., 2011). In this version the main HONO sources include direct emissions from cars with an emission ratio $\mathrm{HONO} / \mathrm{NO}_{\mathrm{x}}=0.008$ between $0.1 \mathrm{~m}$ and $1 \mathrm{~m}$ altitude, based on the tunnel measurement from Kurtenbach et al. (2001). Gas-phase formation of HONO results from the reaction of $\mathrm{NO}$ with $\mathrm{OH}$ (Reaction R3). HONO is also formed from conversion of $\mathrm{NO}_{2}$ on aerosol and ground surfaces, with a yield of $50 \%$ following the stoichiometry of this reaction mechanism and an $\mathrm{NO}_{2}$ reactive uptake coefficient of $10^{-5}$ (Trick, 2004). HONO loss reactions in the model include HONO photolysis (Reaction R1), and the HONO reaction with $\mathrm{OH}$ (Reaction R2). In addition, HONO is taken up on aerosol and ground surfaces with reactive uptake coefficients of $10^{-3}$ and $2 \times 10^{-5}$, respectively, which were used in our previous modeling studies (Wong et al., 2011). We will refer to this parameterization of HONO chemistry as the base case here. It should be added that this model performed well for nocturnal conditions, as shown in Wong et al. (2011).

As previously mentioned, and also discussed below in more detail, the HONO formation mechanisms at night are insufficient to explain daytime HONO levels. We have thus also included parameterizations for three different photolytically enhanced daytime formation mechanisms:

\section{Conversion on the ground}

According to our previous analysis of daytime HONO observations in Houston (Wong et al., 2012), photolytic conversion of $\mathrm{NO}_{2}$ at the ground, proportional to $\left[\mathrm{NO}_{2}\right]$ and solar irradiance, was the most likely source of daytime HONO. Following this idea, we developed a parameterization for this source, which is based on a sunlight dependent $\mathrm{NO}_{2}$ to HONO reactive uptake coefficient at the ground.

As our model, like most other atmospheric chemistry models, relies on a parameterization of the actinic flux/photolysis rates to describe the influence of sunlight on atmospheric chemistry, we first developed a description of solar irradiance as a function of the photolysis rate of $\mathrm{NO}_{2}, J_{\mathrm{NO}_{2}}$. The following equation, which normalizes solar irradiance to 1 at
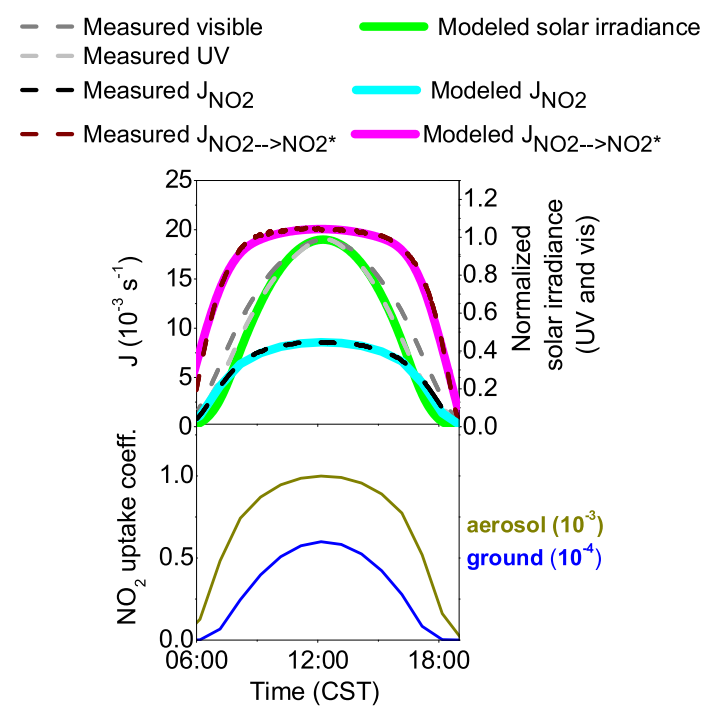

Fig. 1. Upper panel: time series of measured $\mathrm{NO}_{2}$ photolysis frequencies $J_{\mathrm{NO}_{2}}$, photolysis frequency of $\mathrm{NO}_{2}$ to $\mathrm{NO}_{2}^{*}, J_{\mathrm{NO}_{2} \rightarrow \mathrm{NO}_{2} *}$, normalized solar visible irradiance, and UV irradiance are shown as dashed lines (see Wong et al., 2012 for details on the observations). Modeled $J_{\mathrm{NO}_{2}}, J_{\mathrm{NO}_{2} \rightarrow \mathrm{NO}_{2} *}$ and normalized solar irradiance are shown as thick lines. Lower panel: time series of calculated reactive $\mathrm{NO}_{2}$ uptake coefficient on the ground and on aerosol in model runs 2 and 3 .

noon and is based on a cubic dependence on $J_{\mathrm{NO}_{2}}$, was found to be the simplest description of the diurnal variation of solar irradiance:

Irradiance $=$ Max. Irradiance $\cdot \frac{J_{\mathrm{NO}_{2}}^{3}}{J_{\mathrm{NO}_{2}}^{3} \text { at noon }}$

We validated this parameterization with a comparison to the observations of solar irradiance during the three focus days (see Fig. 1). The modeled solar irradiance is within $5 \%$ of the observed UV solar irradiance, which we found previously to better correlate with the photolytic surface source of HONO than the visible solar irradiance (Wong et al., 2012). To overcome the lack of quantitative information on the magnitude of photoenhanced $\mathrm{NO}_{2}$ to $\mathrm{HONO}$ surface conversion on real ground surfaces in the atmosphere, we adjusted the reactive uptake coefficient describing the conversion in model test runs for one day and then applied the result to all other days. The result of this procedure was an uptake coefficient of zero at the time of sunrise and sunset and a maximum of $6 \times 10^{-5}$ at noon. Following laboratory findings (for example George et al., 2005; Stemmler et al., 2006), we assumed a $100 \%$ yield of $\mathrm{HONO}$ for every $\mathrm{NO}_{2}$ molecule being taken up. The final parameterization of the solar irradiance dependent reactive uptake coefficient describing the photoenhanced conversion of $\mathrm{NO}_{2}$ on the ground was then (see also Table 1)

$\gamma \mathrm{NO}_{2}$ ground $=6 \times 10^{-5} \cdot \frac{J_{\mathrm{NO}_{2}}^{3}}{J_{\mathrm{NO}_{2} \text { at noon }}^{3}}$ 
It should be noted that we used this parameterization for all days we analyzed in this study.

\section{Conversion on aerosol}

Similar to the parameterization of photolytic HONO formation at the ground, the photolytic HONO formation on aerosol was parameterized by a $\mathrm{NO}_{2}$ to $\mathrm{HONO}$ reactive uptake coefficient that is a function of the photolysis of $\mathrm{NO}_{2}$.

$\gamma \mathrm{NO}_{2}$ aerosol $=1 \times 10^{-3} \frac{\mathrm{J}_{\mathrm{NO}_{2}}}{J_{\mathrm{NO}_{2} \text { at noon }}}$

Again the, otherwise unknown, multiplicative factor in this expression was chosen to simulate the HONO levels well on the first day and was then applied to the other days as well.

\section{Gas-phase formation}

The only photoenhanced gas-phase reaction parameterized in the model is through the reaction of photoexcited $\mathrm{NO}_{2}$ with water vapor, based on the numbers by Li et al. (2008).

$\mathrm{NO}_{2}+h v(\lambda>420 \mathrm{~nm}) \rightarrow \mathrm{NO}_{2}^{*}$

$\mathrm{NO}_{2}^{*} \stackrel{M}{\longrightarrow} \mathrm{NO}_{2}$

$\mathrm{NO}_{2}^{*}+\mathrm{H}_{2} \mathrm{O} \rightarrow \mathrm{OH}+\mathrm{HONO}$

These three reactions were included in the model. The pho-

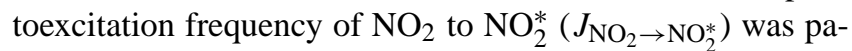
rameterized using a sine function in the model to match it to the observations (Fig. 1). In Sect. 4 we will describe the results of the various parameterizations.

\subsubsection{Model initialization}

The model was initialized at the beginning of the night previous to the respective modeled days, 21 April, 18 and 19 May, using observed concentrations at 18:50 CST (central standard time) on 20 April 2009 and 19:10CST on 17 and 18 May 2009. LP-DOAS observations of $\mathrm{HONO}, \mathrm{NO}_{2}, \mathrm{O}_{3}$ and $\mathrm{SO}_{2}$ profiles and in situ $\mathrm{CO}$ mixing ratios at $70 \mathrm{~m}$ were used. Observed volatile organic compounds concentrations at $70 \mathrm{~m}$, assumed to be constant at all heights, were used in all three model runs (T. Jobson, personal communication, 2010) (Table 2). Aerosol surface area densities of 170, 85 and $180 \mu \mathrm{m}^{2} \mathrm{~cm}^{-3}$ were used in the model runs of 21 April, 18 and 19 May, respectively. These are diurnal averaged aerosol surface area concentrations measured on these days by Rice University and Texas A\&M University (R. Griffin, C. Reed and D. Collins, personal communication, 2010).

As previously described in Geyer and Stutz (2004), nocturnal vertical profiles of most trace gases depend strongly on two factors: vertical stability and $\mathrm{NO}_{\mathrm{x}}$ emission rates. Both parameters are not known well enough for the SHARP data

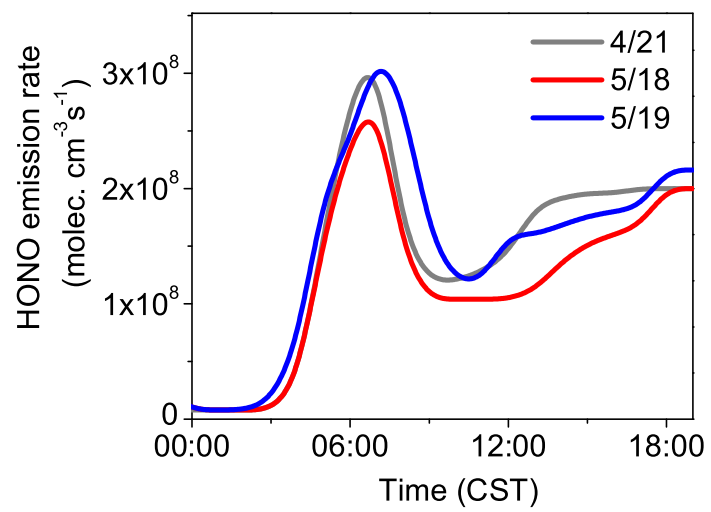

Fig. 2. HONO emission rate in the altitude interval between $0.1-1 \mathrm{~m}$ due to traffic in the model.

to allow an accurate modeling of nocturnal chemistry. To ensure that we describe these two factors correctly before we attempt to simulate $\mathrm{HONO}$ profiles, $\mathrm{NO}_{\mathrm{x}}$ emission rates and vertical mixing were adjusted at each hour at night to make the modeled temporal and vertical profiles of $\mathrm{NO}_{2}$ and $\mathrm{O}_{3}$ fit the measurement. Vertical mixing was adjusted indirectly by varying the Monin-Obukhov length, which was used to calculate the eddy diffusivity. This method was used in our previous modeling studies on nocturnal HONO profiles in Houston, TX, in 2006 (Wong et al., 2011). Sunrise and the onset of photolysis occurred at model hour 11 (or 05:50 CST) on 21 April, 10.25 (or 05:25 CST) on 18 and 19 May.

Daytime boundary layer height measurements performed by the University of Houston during SHARP were used in the model. Boundary layer heights increased from 130, 160 and $100 \mathrm{~m}$ at sunrise to 1500,2800 and $2000 \mathrm{~m}$ in the afternoon on 21 April, 18 and May 19, respectively. Due to the lack of micrometeorological observations during the experiment, vertical mixing during the day is assumed to have a maximum at noontime, when solar radiation peaks, for all model runs. This assumption is supported by previous measurements of eddy diffusivity (Horváth et al, 1998; Constant et al., 2008). In order to reproduce the daytime $\mathrm{NO}_{2}$ observations, the daytime $\mathrm{NO}_{\mathrm{x}}$ emissions were also adjusted. $\mathrm{NO}_{\mathrm{x}}$ emission rates for all three modeling periods were characterized by a morning rush hour period, which peaks at 07:00 CST at about (3-4) $\times 10^{10} \mathrm{molec} \mathrm{cm}^{-3} \mathrm{~s}^{-1}$, and an broad afternoon rush hour, which starts at about 02:00 CST. The shape of the $\mathrm{NO}_{\mathrm{x}}$ emission profile is similar to those reported by Berkowicz et al. (2006) and Marr et al. (2002). As the HONO emission rate was linked to that of $\mathrm{NO}_{\mathrm{x}}$, it was thus also adjusted accordingly, as shown in Fig. 2. Vertical mixing during the day is assumed to be at a maximum at noontime for all model runs.

It should be noted here that the model was not constrained by any observed trace gas concentrations after initialization. 
Table 1. Summary of different model runs.

\begin{tabular}{|c|c|c|}
\hline $\begin{array}{l}\text { Model } \\
\text { runs }\end{array}$ & $\begin{array}{l}\text { Photolytic } \\
\text { HONO source }\end{array}$ & Photolytic HONO formation reactions or parameterizations \\
\hline 1 & None & None \\
\hline 2 & $\begin{array}{l}\mathrm{NO}_{2} \text { conversion at the } \\
\text { ground only }\end{array}$ & $\gamma_{\mathrm{NO}_{2} \text { ground }}=6 \times 10^{-5} \cdot \frac{J_{\mathrm{NO}_{2}}^{3}}{J_{\mathrm{NO}_{2}}^{3} \text { at noon }}, \mathrm{HONO}$ yield $=100 \%$ \\
\hline 3 & $\begin{array}{l}\mathrm{NO}_{2} \text { conversion on } \\
\text { aerosol only }\end{array}$ & $\gamma \mathrm{NO}_{2}$ aerosol $=1 \times 10^{-3} \cdot \frac{J_{\mathrm{NO}_{2}}}{J_{\mathrm{NO}_{2}} \text { at noon }}, \mathrm{HONO}$ yield $=100 \%$ \\
\hline 4 & Gas phase & $\begin{array}{l}\mathrm{NO}+h v(\lambda>420 \mathrm{~nm}) \rightarrow \mathrm{NO}_{2}^{*} \\
\mathrm{NO}_{2}^{*} \stackrel{M}{\longrightarrow} \mathrm{NO}_{2} \\
\mathrm{NO}_{2}^{*}+\mathrm{H}_{2} \mathrm{O} \rightarrow \mathrm{OH}+\mathrm{HONO}\end{array}$ \\
\hline 5 & $\begin{array}{l}\mathrm{NO}_{2} \text { conversion at the } \\
\text { ground and on aerosol }\end{array}$ & $\begin{array}{l}\text { Ground: } \gamma_{\mathrm{NO}_{2} \text { ground }}=6 \times 10^{-5} \cdot \frac{\mathrm{J}_{\mathrm{NO}_{2}}{ }^{3}}{J_{\mathrm{NO}_{2} \text { at noon }}^{3}}, \mathrm{HONO} \text { yield }=100 \% \\
\text { Aerosol: } \gamma_{\mathrm{NO}_{2} \text { aerosol }}=4 \times 10^{-4} \cdot \frac{J_{\mathrm{NO}_{2}}}{J_{\mathrm{NO}_{2} \text { at noon }}}, \mathrm{HONO} \text { yield }=100 \%\end{array}$ \\
\hline
\end{tabular}

Table 2. Initial concentrations in the model in ppb.

\begin{tabular}{lccc}
\hline & 20 April & 17 May & 18 May \\
\hline $\mathrm{HONO}$ & 0.11 & 0.08 & 0.10 \\
$\mathrm{NO}_{2}$ & 15.0 & 4.0 & 9.0 \\
$\mathrm{O}_{3}$ & 52 & 33 & 47 \\
$\mathrm{SO}_{2}$ & 0.35 & 0.03 & 0.52 \\
$\mathrm{CO}$ & 240 & 154 & 183 \\
$\mathrm{CH}_{4}$ & 1600 & 1600 & 1600 \\
Alkanes & 14.4 & 8.2 & 14.6 \\
Alkenes & 4.2 & 0.8 & 3.2 \\
Biogenics & 0.6 & 0.5 & 0.2 \\
Aromatics & 1.5 & 0.6 & 1.3 \\
Carbonlys & 6.5 & 6.1 & 10.1 \\
\hline
\end{tabular}

\section{Results}

We applied our different parameterizations to three days during the SHARP experiment: 21 April, 18 and 19 May. These days were the cloud free days during the experiment that we used in our previous analysis (Wong et al., 2012). The smooth diurnal variation of solar irradiance and actinic flux makes the interpretation of HONO chemistry considerably easier. While our model runs included $10-11 \mathrm{~h}$ before sunrise, we will only show the model results and observations of $\mathrm{HONO}, \mathrm{NO}_{2}$ and $\mathrm{HONO} / \mathrm{NO}_{2}$ ratio from 06:00 to 18:00 CST here. The ability of our model to describe nocturnal vertical profiles of $\mathrm{NO}_{2}$ and $\mathrm{HONO}$ has been described in detail in Wong et al. (2011), and will not be repeated here. While the model results of other trace gases have been compared to observations to ensure that we capture daytime chemistry, we will not show these comparisons here, as the vertical profiles of $\mathrm{NO}_{2}$ and $\mathrm{HONO}$ are most relevant for this study. It should

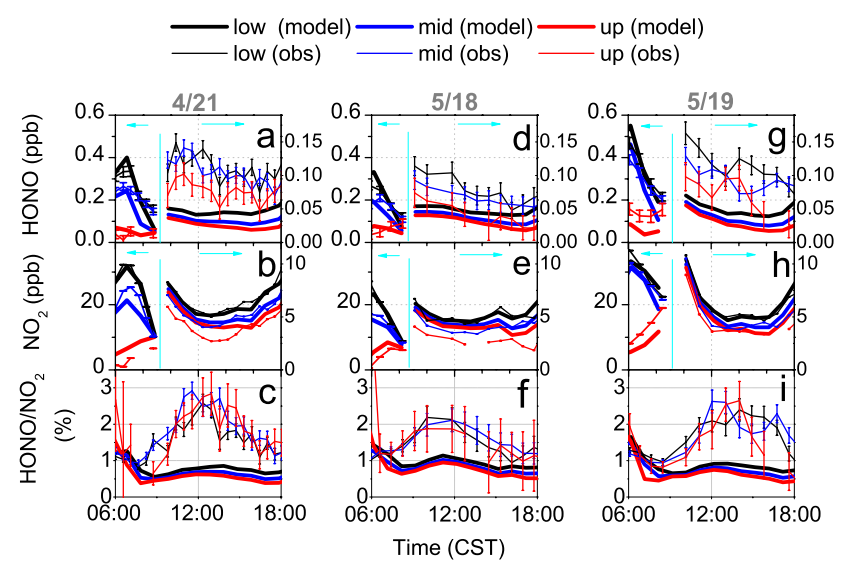

Fig. 3. Comparisons between observations and model results without photolytic HONO source. Shown here are daytime HONO (a, d, $\mathbf{g}), \mathrm{NO}_{2}(\mathbf{b}, \mathbf{e}, \mathbf{h})$, and $\mathrm{HONO} / \mathrm{NO}_{2}$ ratio $(\mathbf{c}, \mathbf{f}, \mathbf{i})$ in the lower (black), middle (blue), and upper (red) height altitudes on 21 April (left panel), 18 May (middle panel), and 19 May (right panel). HONO and $\mathrm{NO}_{2}$ mixing ratios after 09:00 CST were magnified with a different scale on the right axis. Error bars in this figure, and all following figures, represent the 1-sigma statistical uncertainty of the measurements (Wong et al., 2012).

also be noted that in all cases, we applied the same parameterizations of HONO chemistry for all three days.

\subsection{Base model run without photolytic HONO source}

The base model run (No. 1, Table 1) is solely based on the dark conversion of $\mathrm{NO}_{2}$ to HONO that was initially implemented in our nocturnal model exercise (Wong et al., 2011).

Modeled $\mathrm{NO}_{2}$, shown as mixing ratios vertically integrated in the LP-DOAS height intervals in Fig. 3 (panels b, e, 
h), showed good agreement with the observations. The model was able to capture the morning rush hour peaks of $\mathrm{NO}_{2}$ in the lower and middle height intervals on all three days. The modeled $\mathrm{NO}_{2}$ mixing ratios in the middle height intervals were slightly lower than the observations on 21 April. $\mathrm{NO}_{2}$ mixing ratios in the upper height intervals were overestimated on 21 April and 18 May, but were underpredicted on 19 May. Boundary layer height estimated from aerosol backscatter measurements indicated that the upper height interval was in the residual layer in the early morning (Wong et al., 2012). Modeling of vertical mixing is challenging during this period of transition from a stable to a well-mixed boundary layer. Despite the adjustment of vertical mixing, the model most likely did not accurately capture the timing of the onset of enhanced daytime vertical mixing and height of the morning boundary layer (Wong et al., 2011). Nevertheless, the model captured the general features of the observations, i.e., the decrease of $\mathrm{NO}_{2}$ vertical gradients due to photolysis and vertical mixing for all three days.

Throughout the rest of the day, modeled $\mathrm{NO}_{2}$ mixing ratios followed the observations closely, with a steady decrease towards a minimum around, or shortly after, noon, and a slow increase towards the evening. This behavior can be partially explained by the shift in the NO- $\mathrm{NO}_{2}$ photostationary steady state as the $\mathrm{NO}_{2}$ photolysis rate varied throughout the day. The smoothness in the observations, which makes modeling considerably easier, stems from the horizontal path averaging of the LP-DOAS, as well as from the fairly constant meteorological conditions during these days. On all three days, daytime $\mathrm{NO}_{2}$ mixing ratios remained below $10 \mathrm{ppb}$.

Vertical gradients of $\mathrm{NO}_{2}$ were observed on all three days, with lower mixing ratios aloft. The model reproduced the presence of gradients on all three days, except that the model tended to overestimate the $\mathrm{NO}_{2}$ mixing ratios in the upper height intervals on 21 April and 18 May. The reason for the overestimate may be due to the fact that our model did not capture mixing above $150 \mathrm{~m}$ correctly or that there was an influence from advection. Despite some of the discrepancies in the comparison of the model with the observations, the model generally captured the modeled $\mathrm{NO}_{2}$ mixing ratios and vertical profiles well enough to allow a detailed analysis of HONO chemistry.

Early morning HONO mixing ratios in the model agreed well with the observations on all three days (Fig. 3a, d, $\mathrm{g})$. The morning HONO peaks in the lower height intervals tended to be slightly overestimated by the model. This can be caused by the overestimated $\mathrm{HONO} / \mathrm{NO}_{\mathrm{x}}$ emission ratio in the model, since traffic is a significant source of HONO during the early morning rush hour, as shown in Wong et al. (2011). The decrease of HONO concentrations and vertical gradients due to photolysis and vertical mixing was reproduced well in the model. However, after 09:00 CST the modeled HONO mixing ratios were much smaller than the observed mixing ratios on all three days. Small vertical gradients were simulated by the model, as expected from the pho- tolysis of $\mathrm{HONO}$ as it is mixed upwards from the ground. The modeled HONO mixing ratios of $0.05 \mathrm{ppb}$ or less in all three height intervals describe only $50 \%$ or less of the observed mixing ratios on 21 April and 19 May. Only in the upper height interval on 18 May do the modeled HONO mixing ratios fall within the error bars of the observed HONO mixing ratios. Daytime HONO during this model run was predominately from the gas-phase formation from $\mathrm{NO}$ and $\mathrm{OH}$. Contribution from the dark heterogeneous conversion at the ground is less significant. The underestimated HONO mixing ratios in the model clearly indicated a missing daytime HONO source in the base model run, confirming previous findings about a missing daytime HONO source.

As explained in detail in Wong et al. (2012), the $\mathrm{HONO} / \mathrm{NO}_{2}$ ratios offer unique insight into the chemistry of HONO, which for most of the proposed mechanisms involves $\mathrm{NO}_{2}$. Consequently, the $\mathrm{HONO} / \mathrm{NO}_{2}$ ratios were also compared between the model results and the observations (Fig. 3c, f, i). In the very early morning, the model shows good agreement with the observations for all three days. This is mostly explained by the dominance of direct emissions and HONO left over from the previous night. However, for the rest of the day, the model was unable to reproduce the observed magnitude or diurnal variation of the $\mathrm{HONO} / \mathrm{NO}_{2}$ ratios. The observed ratios increased in the morning and reached a maximum at about $2-3 \%$ around noontime, while the modeled ratios stayed below $1 \%$ and did not show a strong diurnal variation. This again confirms the lack of a daytime HONO source in our base model case.

\subsection{Model runs with photolytic HONO source at the ground}

From the comparison of the modeled HONO and $\mathrm{HONO} / \mathrm{NO}_{2}$ ratios in the base case, it is clear that an additional source of HONO during the day is necessary to describe the observations. Our previous analysis, which was based on a correlation analysis of this missing HONO source with solar irradiance and actinic flux, indicated that the most likely source of daytime HONO was a photo-enhanced conversion at the ground (Wong et al., 2012). Consequently, we performed additional model runs for the three focus days with this source included. As discussed above, the diurnal variation of this source was linked to observed variations of the solar irradiance in Houston. The magnitude of this source, however, was adapted to explain the observed HONO mixing ratios. The maximum reactive $\mathrm{NO}_{2} \rightarrow \mathrm{HONO}$ uptake coefficient that best explained our observations was found to be $6 \times 10^{-5}$, which is larger than, but of the same order of magnitude as, the laboratory values reported by Stemmler et al. (2006). One possible reason for the larger uptake coefficient used in the model is that the model assumes a flat ground surface, while true surfaces have larger effective surface areas. Besides adding this new HONO formation pathway, the only other adaptation we made in these model runs 


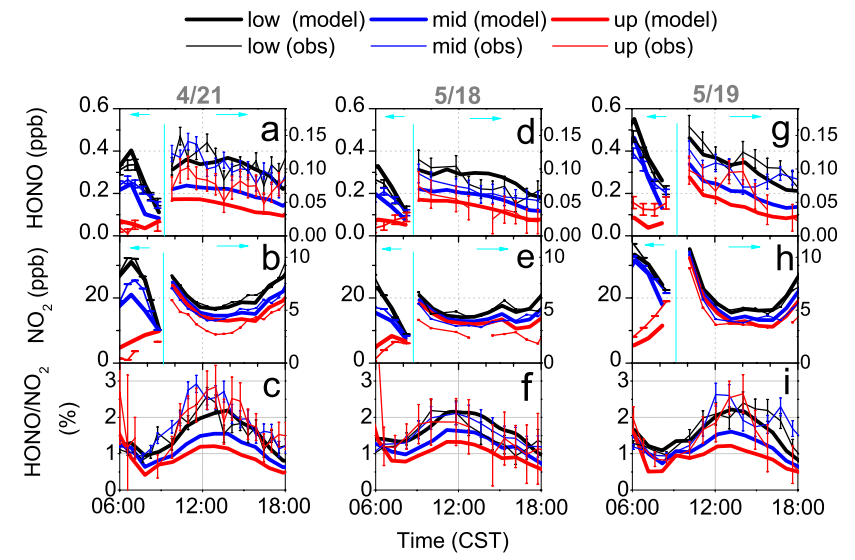

Fig. 4. Comparisons between observations and model results with a photolytic HONO source at the ground. Shown here are daytime $\mathrm{HONO}(\mathbf{a}, \mathbf{d}, \mathbf{g}), \mathrm{NO}_{2}(\mathbf{b}, \mathbf{e}, \mathbf{h})$, and $\mathrm{HONO} / \mathrm{NO}_{2}$ ratios $(\mathbf{c}, \mathbf{f}, \mathbf{i})$ in the lower (black), middle (blue), and upper (red) height altitudes on 21 April (left panel), 18 May (middle panel), and 19 May (right panel). $\mathrm{HONO}$ and $\mathrm{NO}_{2}$ mixing ratios after 09:00 CST were magnified with a different scale on the right axis.

was to slightly increase (by $5 \%$ ) the $\mathrm{NO}_{\mathrm{x}}$ emissions, in order to compensate for the higher $\mathrm{NO}_{2}$ loss in the model due to its conversion to HONO.

After the photolytic HONO source at the ground was implemented in the model, the daytime HONO mixing ratios were significantly increased (Fig. 4). HONO mixing ratios in the lower height intervals showed much better agreement between the model and the observations on all three days. The modeled HONO mixing ratios in the lower height intervals were typically within $\pm 20 \%$ of the observations, and often within the errors of the observations. On 18 May, the modeled HONO mixing ratios in the middle and upper height intervals were also within the errors of the observed mixing ratios. However, on 21 April and 19 May, the modeled HONO mixing ratios in the middle and upper height intervals were still smaller than those observed.

The modeled $\mathrm{HONO} / \mathrm{NO}_{2}$ ratios also showed much better agreement with the observed ratios. In particular, the modeled $\mathrm{HONO} / \mathrm{NO}_{2}$ ratios showed the observed diurnal variations, with a maximum of around $2 \%$ at noon. However, consistent vertical gradients of $\mathrm{HONO} / \mathrm{NO}_{2}$ ratios, which were not observed, were simulated by the model. While the $\mathrm{HONO} / \mathrm{NO}_{2}$ ratios in the lowest height intervals showed good agreement with the observations, the ratios in the middle and upper height intervals were underpredicted by as much as a factor of two by the model.

The low HONO mixing ratios and low $\mathrm{HONO} / \mathrm{NO}_{2}$ ratios in the middle and upper height intervals in the model suggested that either an additional HONO source existed aloft, or that the loss, which proceeds predominately though HONO photolysis, was too large, as HONO formed at the surface is mixed upwards. We investigated the possibility that

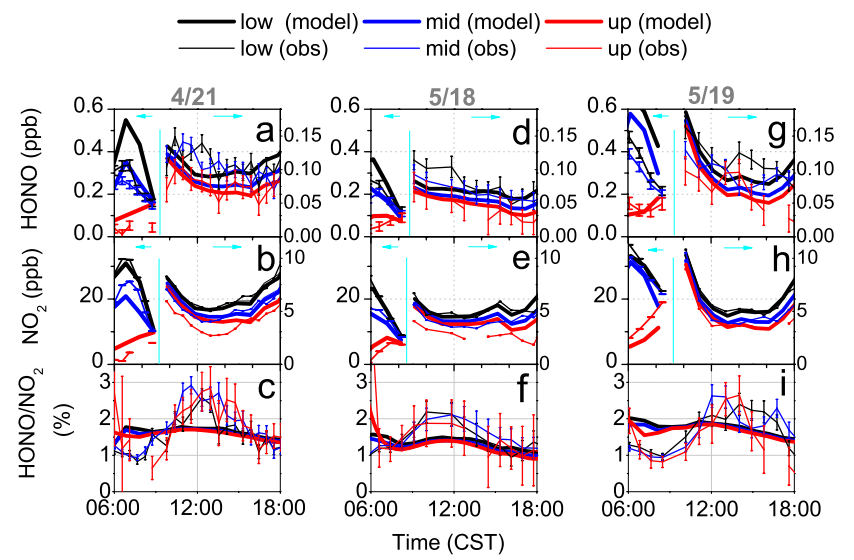

Fig. 5. Comparisons between observations and model results with a photolytic HONO source on aerosol only. Shown here are daytime $\mathrm{HONO}(\mathbf{a}, \mathbf{d}, \mathbf{g}), \mathrm{NO}_{2}(\mathbf{b}, \mathbf{e}, \mathbf{h})$, and $\mathrm{HONO} / \mathrm{NO}_{2}$ ratios $(\mathbf{c}, \mathbf{f}, \mathbf{i})$ in the lower (black), middle (blue), and upper (red) height altitudes on 21 April (left panel), 18 May (middle panel), and 19 May (right panel). $\mathrm{HONO}$ and $\mathrm{NO}_{2}$ mixing ratios after 09:00 CST were magnified with a different scale on the right axis.

mixing in the model is too slow, leading to a much faster decay of HONO with altitude. However, any attempt to increase vertical mixing in the model led to unrealistic vertical gradients of $\mathrm{NO}_{2}$ and other trace gases (not shown). We therefore concluded that the most likely reason for low HONO aloft in the model is the presence of another HONO source (see Sect. 3.4).

\subsection{Model runs with source on aerosol or in gas phase only}

To test if our observations of daytime HONO could be explained by photoenhanced conversion of $\mathrm{NO}_{2}$ on the aerosol or through the gas-phase reaction of $\mathrm{NO}_{2}^{*}$ with water vapor (see Table 1), we performed two sets of model runs with each of these formation mechanisms (Figs. 5 and 6).

Model runs with a daytime HONO source on aerosol showed HONO mixing ratios of within $\pm 20 \%$ of the observations at all height intervals, except that the morning peaks were overestimated in the lower and/or middle height intervals. The HONO mixing ratios in the upper height intervals were over-predicted/under-predicted due to the overestimated/underestimated $\mathrm{NO}_{2}$ mixing ratios in the model.

While the absolute values of HONO and the general diurnal variation based on these the aerosol formation mechanisms agree well between model and observations, the $\mathrm{HONO} / \mathrm{NO}_{2}$ ratios reveal a different picture. Modeled $\mathrm{HONO} / \mathrm{NO}_{2}$ ratios did not reproduce the observed diurnal variations. While the observations on all three days clearly show a profile with a maximum around noon, the modeled $\mathrm{HONO} / \mathrm{NO}_{2}$ changed little throughout the day. The lack of diurnal variation of the $\mathrm{HONO} / \mathrm{NO}_{2}$ ratios in the model 


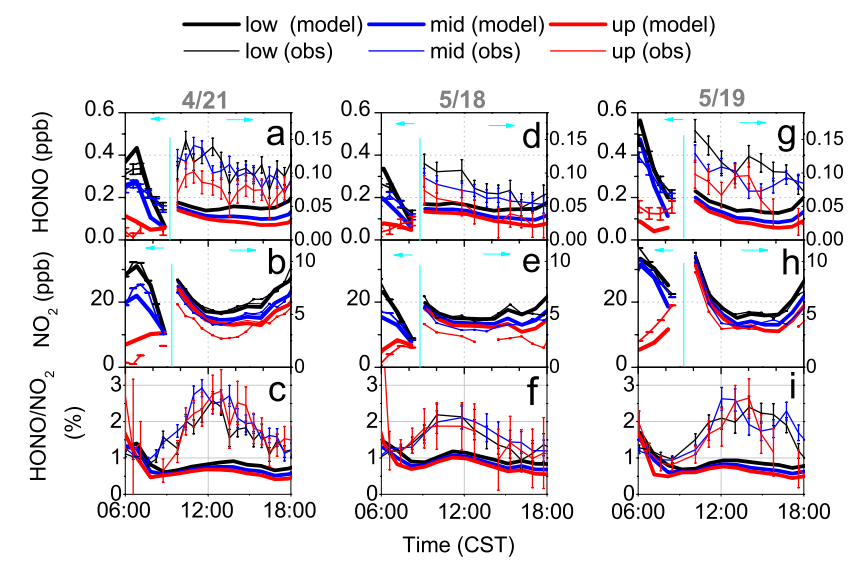

Fig. 6. Comparisons between observations and model results with photolytic HONO gas-phase formation from $\mathrm{NO}_{2}^{*}+\mathrm{H}_{2} \mathrm{O}$ ( $\mathrm{Li}$ et al., 2008) only. Shown here are daytime $\mathrm{HONO}(\mathbf{a}, \mathbf{d}, \mathbf{g}), \mathrm{NO}_{2}(\mathbf{b}, \mathbf{e}, \mathbf{h})$, and $\mathrm{HONO} / \mathrm{NO}_{2}$ ratios $(\mathbf{c}, \mathbf{f}, \mathbf{i})$ in the lower (black), middle (blue), and upper (red) height altitudes on 21 April (left panel), 18 May (middle panel), and 19 May (right panel). $\mathrm{HONO}$ and $\mathrm{NO}_{2}$ mixing ratios after 09:00 CST were magnified with a different scale on the right axis.

runs with aerosol formation was consistent with our previous analysis (Wong et al., 2012), and stems from the cancellation of the photolytic dependence of the formation mechanism and the photolytic HONO loss. Our previous analysis using a steady-state approximation showed that the diurnal variation of $\mathrm{HONO} / \mathrm{NO}_{2}$ is proportional to the ratio of $J_{\mathrm{NO}_{2}}$ to $J_{\mathrm{HONO}}$, assuming that photolytic $\mathrm{NO}_{2}$ conversion on aerosol is the primary formation of HONO during the day and photolysis is the major removal pathway. Because both $J_{\mathrm{NO}_{2}}$ and $J_{\mathrm{HONO}}$ occur in a similar spectral region, their ratio shows almost no diurnal variation.

The model results with photolytic gas-phase HONO formation from $\mathrm{NO}_{2}^{*}+\mathrm{H}_{2} \mathrm{O}$ (Fig. 6) showed much smaller HONO mixing ratios than the observations on all three days. The HONO mixing ratios were similar to those when no daytime HONO source was considered in the model (Fig. 3). Modeled $\mathrm{HONO} / \mathrm{NO}_{2}$ ratios were significantly less than the observed ratios and did not show the observed diurnal variations.

With our choice of aerosol reactive uptake coefficient (Table 1), the model was able to reproduce the general mixing ratios and behavior of daytime HONO. A closer look at the $\mathrm{HONO} / \mathrm{NO}_{2}$ ratios, however, revealed that the underlying chemical mechanisms have clear flaws. We likely chose an aerosol uptake coefficient that was too high. Even with the rate constant suggested by Li et al. (2008), the gas-phase mechanism through $\mathrm{NO}_{2}^{*}$ is too slow to reproduce the observed daytime HONO mixing ratios. This confirms other studies that found this mechanism to be unimportant (Carr et al., 2009; Amedro et al., 2011). We can therefore conclude that aerosol formation alone cannot be the dominant source

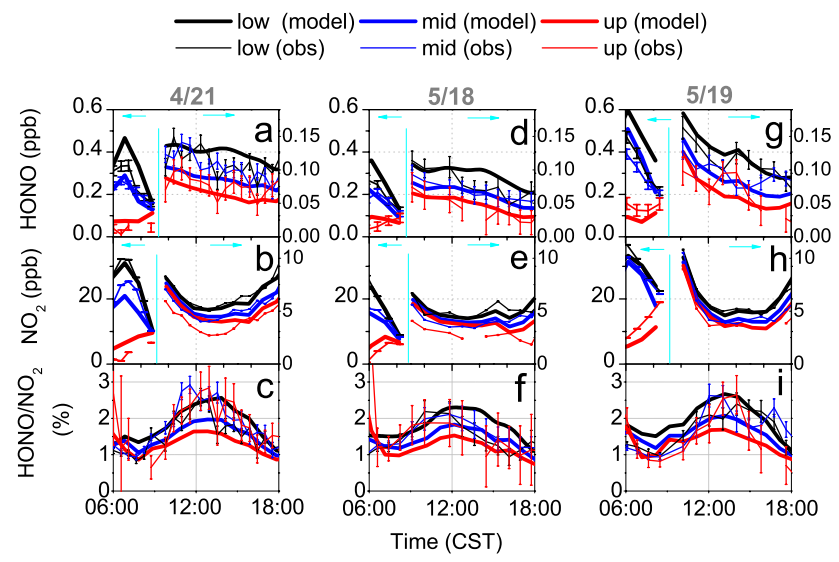

Fig. 7. Comparisons between observations and model results with a photolytic HONO source at the ground and on aerosol. Shown are daytime $\mathrm{HONO}(\mathbf{a}, \mathbf{d}, \mathbf{g}), \mathrm{NO}_{2}(\mathbf{b}, \mathbf{e}, \mathbf{h})$, and $\mathrm{HONO} / \mathrm{NO}_{2}$ ratios (c, f, i) in the lower (black), middle (blue), and upper (red) height altitudes on 21 April (left panel), 18 May (middle panel), and 19 May (right panel). $\mathrm{HONO}$ and $\mathrm{NO}_{2}$ mixing ratios after 09:00 CST were magnified with a different scale on the right axis.

of daytime HONO and, that the gas-phase reactions of $\mathrm{NO}_{2}^{*}$ $+\mathrm{H}_{2} \mathrm{O}$ is negligible in daytime HONO formation.

\subsection{Model runs with photolytic HONO formation both at the ground and on aerosol}

While the formation of HONO through the photoenhanced conversion of $\mathrm{NO}_{2}$ on the surface provided a good description of the lower height interval, HONO levels were too low in the middle and upper intervals. One possible explanation for the observations would be the presence of an open-air HONO source. While we showed in Sect. 3.5 that open air sources such as the conversion of $\mathrm{NO}_{2}$ to $\mathrm{HONO}$ on the aerosol alone do not explain HONO, we have no reason to completely exclude these mechanisms. However, the gasphase reactions of $\mathrm{NO}_{2}^{*}+\mathrm{H}_{2} \mathrm{O}$ were found to be unimportant for daytime HONO formation (Sect. 3.5), and will not be further considered here. Consequently we performed a model run implementing both the aerosol source and the ground source described previously. We used the same uptake coefficients on the ground as in our previous model runs $\left(6 \times 10^{-5}\right.$ on the ground), but a smaller uptake coefficient of $4 \times 10^{-4}$ on aerosol for all three days (Case 5, Table 1). $\mathrm{NO}_{\mathrm{x}}$ emissions were again slightly increased to fit the modeled $\mathrm{NO}_{2}$ mixing ratios better to the observations.

The inclusion of both sources (Fig. 7) increases the HONO mixing ratios on all three height intervals. This is particularly obvious in the middle and upper height intervals where HONO increased significantly on 21 April and 19 May. The modeled HONO vertical gradients between the lower and middle intervals were sometimes larger than the observations, and the model sometimes slightly overpredicted HONO mixing ratios in the lower height intervals. The 

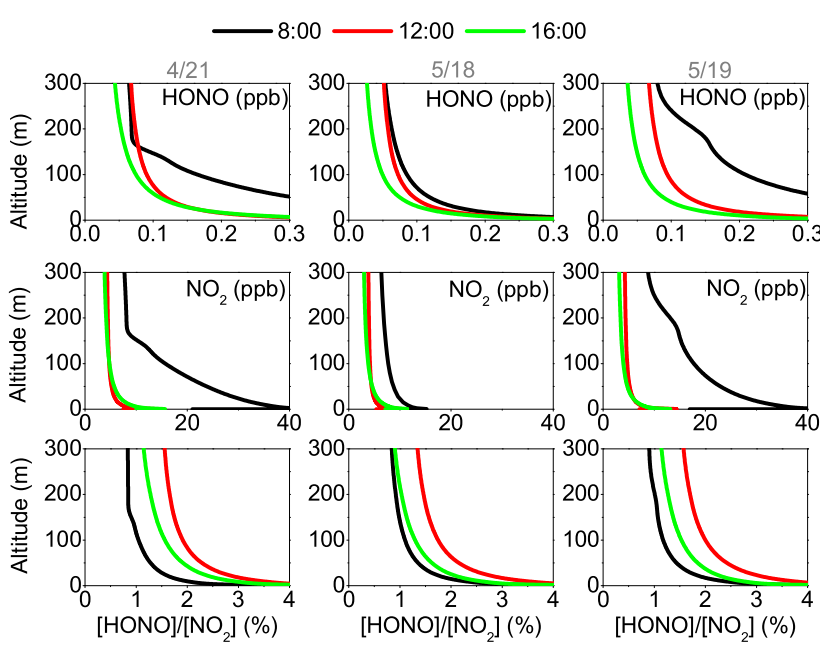

Fig. 8. Modeled vertical profiles of daytime HONO (upper panel), $\mathrm{NO}_{2}$ (middle panel) and $\mathrm{HONO} / \mathrm{NO}_{2}$ ratios (lower panel) at 08:00, 12:00, and 16:00 CST on 21 April, 18 May, and 19 May. Results are from model runs with photolytic HONO sources at the ground and on aerosol.

morning peaks of HONO mixing ratios were overestimated in the model on all three days, most likely pointing to either a smaller HONO source from direct emissions, or a missing morning sink. Sörgel et al. (2011a), who also observed a missing HONO sink in the early morning in a rural area, suggested that the missing sink could be due to deposition. Nevertheless, our modeled and observed HONO agrees within $\pm 15 \%$ on all three days on all light paths, which is in most cases within the measurement error.

The modeled $\mathrm{HONO} / \mathrm{NO}_{2}$ ratios in Case 5, with both sources, showed better agreement with the observations than Case 2, with a ground source alone. Nevertheless the ratios still consistently show vertical gradients which, despite the errors in the observations, were not seen in Houston. The reason for this difference is currently unclear. One possible explanation is that the overestimated $\mathrm{NO}_{2}$ mixing ratios in upper height intervals of the model causes the $\mathrm{HONO} / \mathrm{NO}_{2}$ ratios to be too low aloft. If we calculate the ratio based on the modeled $\mathrm{HONO}$ and observed $\mathrm{NO}_{2}$ in the upper height interval, the $\mathrm{HONO} / \mathrm{NO}_{2}$ ratios would be simulated very well and the $\mathrm{HONO} / \mathrm{NO}_{2}$ ratios in the upper height intervals would be similar to those in the middle height intervals. The vertical gradients of $\mathrm{HONO} / \mathrm{NO}_{2}$ ratios would also be smaller, which would be more consistent with the observations.

The comparisons between our three cases suggest that the best description of daytime HONO chemistry in Houston can be achieved by a combination of photoenhanced conversion of $\mathrm{NO}_{2}$ on the ground and on the aerosol. The contribution of each of these mechanisms to the HONO budget will be discussed in the next section.

\section{Discussion}

Our sensitivity model runs indicated that a combination of photoenhanced formation of HONO at the ground and on the aerosol lead to the best agreement of daytime HONO and $\mathrm{HONO} / \mathrm{NO}_{2}$ ratios between the model and the observations. To further elucidate the vertical HONO profiles, as well as the contribution of the HONO formation and loss pathways, we analyzed the details of the model run, including both the photoenhanced aerosol and ground sources.

Figure 8 shows the modeled vertical profiles of HONO, $\mathrm{NO}_{2}$ and $\mathrm{HONO} / \mathrm{NO}_{2}$ ratios at 08:00, 12:00 and 16:00 CST on 21 April, 18 and 19 May. $\mathrm{NO}_{2}$ showed strong vertical profiles at 08:00 CST in the morning of 21 April and 19 May. In contrast, the profiles were much less pronounced on 18 May. The profiles clearly showed that during this time the boundary layer was shallower on 21 April and 19 May than on 18 May. Boundary layer height data estimated from simultaneous aerosol backscatter observations showed that during this time mixed layer height was 190, 330, and $410 \mathrm{~m}$ on 21 April, 18 and 19 May respectively. Later during the day, $\mathrm{NO}_{2}$ profiles on all three days were fairly weak, with the strongest gradients in the lowest $30-50 \mathrm{~m}$, where $\mathrm{NO}_{2}$ was still strongly influenced by surface emissions. However, because the model overpredicted the $\mathrm{NO}_{2}$ mixing ratios in the upper height intervals, the actual $\mathrm{NO}_{2}$ vertical gradients at 12:00 and 16:00 CST were most likely stronger (see Sect. 3.1).

The influence of the morning surface inversions on 21 April and 19 May were also clearly visible in the HONO mixing ratios, which were larger than 0.3 ppb below $50 \mathrm{~m}$ altitude on both mornings. The model overpredicted morning HONO mixing ratios in the lower height intervals and the actual vertical profiles at 08:00 CST were, thus, somewhat less pronounced on these days. The reason for this overprediction was most likely a missing $\mathrm{HONO}$ sink or $\mathrm{HONO} / \mathrm{NO}_{\mathrm{x}}$ emissions ratios, which were set too high for Houston as previously mentioned. Vertical profiles of HONO were still present at noon and in the afternoon, with strong vertical gradients below $50 \mathrm{~m}$. At noon, HONO mixing ratios decreased from $0.2 / 0.15 / 0.2 \mathrm{ppb}$ at $15 \mathrm{~m}$ to $0.09 / 0.06 / 0.09 \mathrm{ppb}$ at $100 \mathrm{~m}$ altitude on 21 April, 18 and 19 May, respectively. We will further investigate the reason for these profiles below.

$\mathrm{HONO} / \mathrm{NO}_{2}$ ratios followed the diurnal behavior, with a maximum at noon at all altitudes. $\mathrm{HONO} / \mathrm{NO}_{2}$ ratios also showed consistent vertical profiles in the model. Interestingly, the impact of the morning inversion was not as obvious as for $\mathrm{HONO}$ and $\mathrm{NO}_{2}$ alone. It, therefore, seems that the $\mathrm{HONO} / \mathrm{NO}_{2}$ ratios are not as impacted by vertical mixing as the individual mixing ratios. 

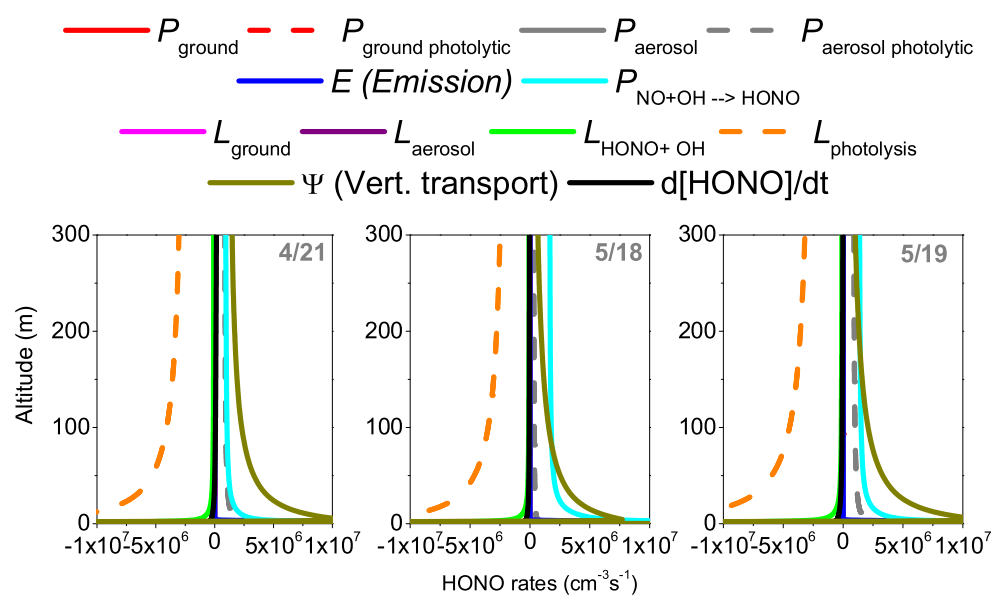

Fig. 9. Vertical profiles of the modeled HONO formation and loss pathways in the lowest $300 \mathrm{~m}$ at noon on 21 April, $18 \mathrm{May}$, and $19 \mathrm{May}$. The vertical transport term describes how much HONO is added or removed by vertical transport at each altitude.

\subsection{Vertical profiles of HONO formation and loss rates}

We further investigated the different formation and removal pathways of HONO in the lowest $300 \mathrm{~m}$ of the boundary layer in order to understand the altitude dependent chemistry behind daytime HONO. Figure 9 shows the vertical profiles of the modeled HONO formation and loss rates at noon on 21 April, 18 and 19 May. There was a clear vertical dependence of the different formation and loss pathways of $\mathrm{HONO}$ on all three days, and the basic shape of the vertical profiles looked similar on all three days. The largest contribution to the formation of $\mathrm{HONO}$ is the photolytic conversion of $\mathrm{NO}_{2}$ on the ground (not directly shown in Fig. 9). The formation fluxes, expressed as molecules per surface area and time, were $1.7 \times 10^{11}, 1.4 \times 10^{11}$ and $1.8 \times 10^{11} \mathrm{molec} \mathrm{cm}^{-2} \mathrm{~s}^{-1}$ on 21 April, 18 and 19 May, respectively. The photolytic HONO formation fluxes at the ground were more than 10 times larger than the non-photolytic ground formation fluxes. To compare the ground source with the volume sources we averaged this formation rate over the lowest $300 \mathrm{~m}$ of the atmosphere to derive a volume formation rate of $5.7 \times 10^{6}, 4.7 \times 10^{6}$ and $6.0 \times 10^{6} \mathrm{molec} \mathrm{cm}^{-3} \mathrm{~s}^{-1}$ at noon on 21 April, 18 and 19 May, respectively. The comparison of these numbers with the values of other HONO formation pathways in Fig. 9 clearly showed the significance of the photolytic ground source. Direct emission also occurred between $0.1-1 \mathrm{~m}$ above the ground at rates of 1.0 $1.6 \times 10^{8}$ molec $\mathrm{cm}^{-3} \mathrm{~s}^{-1}$. In Fig. 9, both ground formation and direct emissions manifest themselves as a vertical transport term, $\Psi$. On all three days, vertical transport was an important source of HONO above $10 \mathrm{~m}$ altitude, with maximum rates of $3.2-4.2 \times 10^{8}$ molec $\mathrm{cm}^{-3} \mathrm{~s}^{-1}$ near the ground and $1.1-1.8 \times 10^{6}$ molec $\mathrm{cm}^{-3} \mathrm{~s}^{-1}$ at $150 \mathrm{~m}$. HONO formation from the gas-phase reaction of $\mathrm{NO}$ and $\mathrm{OH}$ peaked near the ground at rates of $4.1-5.3 \times 10^{7} \mathrm{molec} \mathrm{cm}^{-3} \mathrm{~s}^{-1}$ and decreased with altitude, but stayed about constant at rates of $1.0-1.7 \times 10^{6}$ molec $\mathrm{cm}^{-3} \mathrm{~s}^{-1}$ above $50 \mathrm{~m}$. It should be noted that the modeled NO mixing ratios at $70 \mathrm{~m}$ altitude were within $15 \%$ of the observations, and that the modeled $\mathrm{OH}$ concentrations were within the uncertainty of the measurements (not shown). Photolytic formation of HONO on aerosol also had a similar vertical profile. This pathway was insignificant on 18 May, due to the lower aerosol levels. Its magnitude was comparable to the gas-phase formation on 21 April and 19 May.

Photolysis was the major sink of HONO in the lowest $300 \mathrm{~m}$. It peaked at the ground, where HONO mixing ratios were largest, and decreased with altitude. Photolysis led to loss rates of $3.2-3.7 \times 10^{8} \mathrm{molec} \mathrm{cm}^{-3} \mathrm{~s}^{-1}$ near the ground and $3.5-3.8 \times 10^{6} \mathrm{molec} \mathrm{cm}^{-3} \mathrm{~s}^{-1}$ at $150 \mathrm{~m}$. As this loss process leads to the formation of $\mathrm{OH}$ radicals, one expects a larger impact on the $\mathrm{OH}$ budget near the surface than aloft. This topic will be investigated in more detail in an upcoming publication. Vertical transport was the major loss of HONO at the ground, with fluxes of $1.1-1.4 \times 10^{11}$ molec $\mathrm{cm}^{-2} \mathrm{~s}^{-1}$, followed by deposition with fluxes of $4.2-5.6 \times 10^{10}$ molec $\mathrm{cm}^{-2} \mathrm{~s}^{-1}$ (not shown in Fig. 9). HONO was, thus, being formed at the ground and transported upward, while its mixing ratio decreased due to photolysis.

The diurnal evolution of HONO formation and loss processes integrated over the lowest $20 \mathrm{~m}$ and between 200 $300 \mathrm{~m}$ are shown in Fig. 10. Photolytic HONO formation at the ground was the dominant formation pathway of HONO in the lowest $20 \mathrm{~m}$. It contributed $64-65 \%$ of HONO formation in the lowest $20 \mathrm{~m}$ during the day. It peaked around noon due to its dependence on solar radiation. The asymmetric shape in the morning and in the afternoon was due to the diurnal variation of $\mathrm{NO}_{2}$ mixing ratios, as explained in Wong et al. (2012). HONO direct emission, its gas-phase formation and the photolytic formation on aerosol, which were $13-15 \%$, 6-9\% and $0.6-2.6 \%$ of HONO formation respectively, were 
Table 3. Percentage contribution of the different HONO formation and loss processes averaged in lowest $300 \mathrm{~m}$ above ground.

\begin{tabular}{|c|c|c|c|c|c|c|c|c|c|c|c|c|c|c|}
\hline & \multicolumn{7}{|c|}{ Production } & \multicolumn{6}{|c|}{ Loss } & \multirow{2}{*}{$\begin{array}{l}\text { Net } \\
\left(10^{14} \mathrm{~cm}^{-2}\right)\end{array}$} \\
\hline & $\begin{array}{l}\text { Ground } \\
(\%)\end{array}$ & $\begin{array}{l}\text { Ground } \\
\text { (photo) } \\
(\%)\end{array}$ & $\begin{array}{l}\text { Aerosol } \\
(\%)\end{array}$ & $\begin{array}{l}\text { Aerosol } \\
\text { (photo) } \\
(\%)\end{array}$ & $\begin{array}{l}\text { Emiss. } \\
(\%)\end{array}$ & $\begin{array}{l}\mathrm{NO}+ \\
\mathrm{OH} \\
(\%)\end{array}$ & $\begin{array}{l}\text { Total } \\
\left(10^{15} \mathrm{~cm}^{-2}\right)\end{array}$ & $\begin{array}{l}\text { Ground } \\
(\%)\end{array}$ & $\begin{array}{l}\text { Aerosol } \\
(\%)\end{array}$ & $\begin{array}{l}\text { HONO } \\
+\mathrm{OH} \\
(\%)\end{array}$ & $\begin{array}{l}\text { Vert. } \\
\text { Trans. } \\
(\%)\end{array}$ & $\begin{array}{l}\text { Photo. } \\
(\%)\end{array}$ & $\begin{array}{l}\text { Total } \\
\left(10^{15} \mathrm{~cm}^{-2}\right)\end{array}$ & \\
\hline $4 / 21$ & 10 & 49 & $<1$ & 15 & 10 & 16 & 8.7 & 19 & 1 & 2 & 20 & 58 & 8.5 & 1.8 \\
\hline $5 / 18$ & 8 & 47 & $<1$ & 7 & 10 & 28 & 6.8 & 17 & $<1$ & 2 & 24 & 57 & 6.7 & 1 \\
\hline $5 / 19$ & 7 & 46 & $<1$ & 16 & 8 & 22 & 10 & 17 & 1 & 2 & 18 & 62 & 9.9 & 1.9 \\
\hline
\end{tabular}

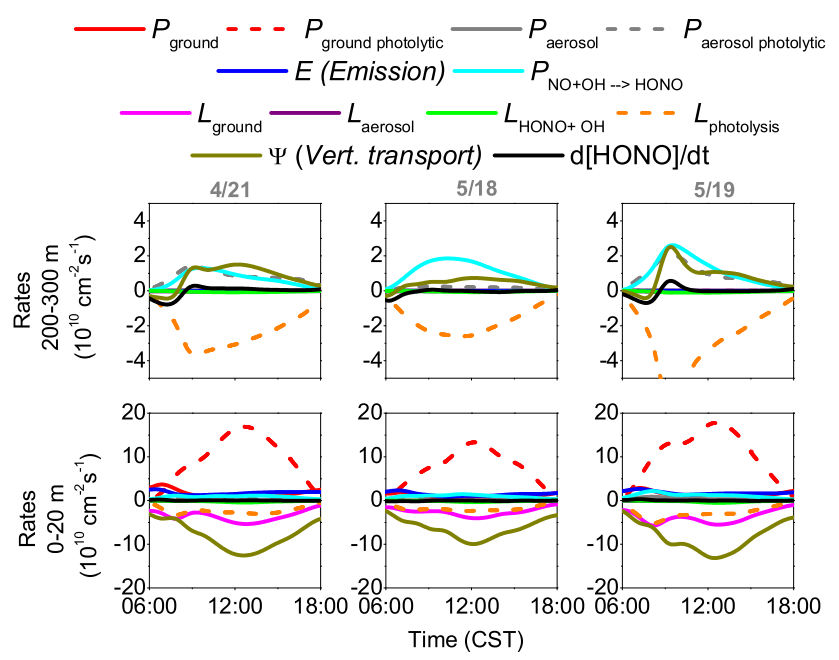

Fig. 10. Timeseries of the integrated HONO formation and loss rates in the lowest $20 \mathrm{~m}$ (lower panels) and between 200-300 m (upper panels) on 21 April, 18 May, and 19 May.

minor sources of HONO in the lowest $20 \mathrm{~m}$. Vertical transport, which depends on the vertical gradients of HONO and the eddy diffusivity, peaked around noon and was the major sink of HONO in the lowest $20 \mathrm{~m}$, leading to $56-59 \%$ of HONO loss, followed by deposition (24-25\%) and photolysis (16-18\%). The fact that photolysis is not the dominant loss process of HONO near the surface, where most previous HONO measurements have been performed, shows that the analysis of the HONO budget has to include the transport term. Simple 0-dimensional budget calculations based on the photolysis as the only loss process will otherwise underestimate the source strength of HONO considerably.

Between 200-300 $\mathrm{m}$ altitude, i.e., removed from the surface sources and direct emissions from traffic, gas-phase reaction, photolytic formation on aerosol, and vertical transport were the main formation pathways of daytime HONO. Gas-phase formation, which was responsible for 30-60\% of daytime HONO formation between $200-300 \mathrm{~m}$, was a major source of HONO, followed by vertical transport, which lead to $26-35 \%$ of daytime HONO formation in this altitude interval. Photolytic HONO formation on aerosol contributed 10-36\% to daytime HONO formation between 200-300 m. On 18 May, photolytic aerosol formation was less important, based on our model results, because of the small observed aerosol surface area density. The main removal of HONO between $200-300 \mathrm{~m}$ was due to photolysis. This loss rate peaked in the morning, due to the combined diurnal variation of the HONO mixing ratios and the HONO photolysis frequency. This was responsible for 96-97\% of HONO removal at this altitude. HONO uptake on aerosol surface and reaction with $\mathrm{OH}$ were unimportant removal pathways of HONO.

\subsection{Vertically integrated HONO formation and loss rates over lowest $300 \mathrm{~m}$}

To further quantify the overall importance of the different altitude dependent HONO formation and loss pathways in our model, and to reduce the influence of vertical mixing, we integrated the formation and loss pathways over the lowest $300 \mathrm{~m}$ throughout the day, i.e., between sunrise and sunset, and compared them to each other (Table 3). The total production of HONO integrated over the lowest $300 \mathrm{~m}$ of the atmosphere and time was $6.8-10 \times 10^{15} \mathrm{molec} \mathrm{cm}^{-2}$, which was balanced by its removal. Daytime HONO formation was dominated by the photoenhanced $\mathrm{NO}_{2}$ conversion on the ground, which contributed $46-49 \%$ of total daytime HONO formation, followed by the gas-phase reaction of $\mathrm{NO}$ with $\mathrm{OH}$, which contributed to $16-28 \%$ to total formation, and photoenhanced HONO formation on aerosol with $7-16 \%$ contribution. Non-photoenhanced HONO formation at the ground from $\mathrm{NO}_{2}$ conversion was $7-10 \%$, similar to the magnitude of direct emission, which was $8-10 \%$ of total HONO formation during the day. HONO formation from $\mathrm{NO}_{2}$ non-photolytic conversion on aerosol did not play a significant role. As expected, photolysis was the largest loss of HONO, resulting in 57-62\% of total daytime HONO removal. Deposition on the ground and vertical transport played secondary roles in HONO loss, contributing to $17-$ $19 \%$ and $18-24 \%$ of total removal. HONO loss on aerosol and by reaction with $\mathrm{OH}$ were minor.

These results can be compared to the values reported by Czader et al. (2012). In their study, which is based on observations in Houston in 2006, the photoenhanced formation on surfaces contributed $61 \%$ to HONO daytime formation in the lowest $34 \mathrm{~m}$ of the atmosphere. This is very close to our results, which show $64 \%$ contribution from photoenhanced formation on ground and aerosol in the lowest $35 \mathrm{~m}$. Our study showed that photoenhanced HONO formation on aerosol was negligible at the surface. Unfortunately, 
the relative importance of ground and aerosol surfaces are not reported in their studies. Contributions from other sources are also not quantitatively reported and can therefore not be compared. As for the removal pathways of HONO, Czader et al. (2012) found that vertical transport contributed $65 \%$ to the daytime HONO loss in the lowest $34 \mathrm{~m}$, while our study shows a smaller contribution of $51 \%$. However, the contribution by dry deposition in their study (12\%) was half of what we found. For chemical loss, Czader et al. (2012) reported $24 \%$ of HONO removal due to reaction with $\mathrm{OH}$. This is much larger than our results, which showed less than $2 \%$ contribution. Sarwar et al. (2008) also concluded that photoenhanced HONO formation was necessary to explain observed daytime HONO levels, although they assumed that the main process is surface nitrate photolysis, a mechanism we did not consider based on our earlier analysis of the field observations in Houston (Wong et al., 2012).

\section{Conclusions}

A 1-D chemistry and transport model was used to reproduce the vertical gradients of $\mathrm{HONO}, \mathrm{NO}_{2}$ and the $\mathrm{HONO} / \mathrm{NO}_{2}$ ratios observed during the SHARP 2009 experiment in Houston, TX, and to investigate potential daytime HONO formation pathways. Daytime HONO mixing ratios and $\mathrm{HONO} / \mathrm{NO}_{2}$ ratios in all height intervals were underestimated by approximately $50 \%$ when only dark HONO formation pathways were considered, which were sufficient to explain nocturnal HONO at the same location previously (Wong et al., 2011). Model scenarios with photoenhanced conversion of $\mathrm{NO}_{2}$ on the ground and the aerosol, as well as the gas-phase HONO formation through photoexcited $\mathrm{NO}_{2}$, showed that the formation pathway that best explained our observations, and in particular those of the $\mathrm{HONO} / \mathrm{NO}_{2} \mathrm{ra}-$ tios, was $\mathrm{NO}_{2}$ conversion at the ground. The inability to reproduce the vertical profiles of $\mathrm{HONO}$ and $\mathrm{HONO} / \mathrm{NO}_{2}$ led to the conclusion that photoenhanced $\mathrm{NO}_{2}$ conversion on aerosol was a likely contributor to HONO formation above $100 \mathrm{~m}$ altitude. The parameterization that led to the best description of HONO was based on a maximum reactive uptake coefficient at noon of $6 \times 10^{-5}$ that was scaled with the normalized spectral irradiance and $100 \%$ yield of $\mathrm{NO}_{2}$ to HONO. This uptake coefficient is larger than those found on organics and urban grime in laboratory studies (for example George et al., 2005; Brigante et al., 2008; Ammar et al., 2010). However, the true atmospheric surface area available for chemistry is likely larger than the geometric surface area used in the model, thus explaining the need for a larger uptake coefficient in the model. The reactive $\mathrm{NO}_{2}$ uptake on aerosol implied by our model study is higher than that reported from laboratory studies (for example Stemmler et al., 2007; Woodill and Hinrichs, 2010), and the reason for this discrepancy is currently unclear. It is possible that other mechanisms, thus far not considered, are acting in the atmosphere.

Our modeling results have a number of interesting implications for the chemistry of HONO and interpretation of field data. The model clearly shows that ground surfaces play a crucial role for HONO levels in the atmosphere. Urban airshed models currently do not have the ability to simulate chemical transformations on the surface, and highly simplified parameterizations are used in most cases (Czader et al., 2012; Gonçalves et al., 2012; Sarwar et al., 2009), many of which have not been extensively tested. More research is needed to understand the processes occurring on true surfaces to better understand HONO. Zhang et al. (2009) and Häseler et al. (2009) suggested that vertical mixing has a large impact on daytime HONO vertical gradients due to the observation of weakening HONO vertical profiles in convective boundary layers. However, no further investigations on vertical mixing have been carried out in these studies. Our model also shows that vertical transport plays a crucial role in distributing HONO from its surface source(s) to the entire boundary layer. Between 56-59\% of the HONO loss in the lowest $20 \mathrm{~m}$ of the atmosphere is due to upward transport, $25 \%$ by deposition, and only $16-18 \%$ due to photolysis. Therefore, care must be taken to interpret in situ HONO observations near the surface, as photolysis is not the main loss pathway at this altitude during the day. Pseudo steady state budget calculations, which are often used to calculate the missing daytime HONO source (such as Kleffmann, 2007; Sörgel et al., 2011a; Wong et al., 2012), may thus underestimate the daytime HONO source. As a consequence of the vertical HONO profile observed and modeled in our study, one can expect that the $\mathrm{OH}$ formation rate due to HONO photolysis is also altitude dependent. More research is needed to understand if this altitude dependence impacts boundary layer chemistry.

Acknowledgements. This work was funded by the State of Texas through the Texas Commission of Environmental Quality, the Houston Advanced Research Center, and the Air Quality Research Program of the University of Texas. Funding was also provided by a National Science Foundation (NSF) Career Award (ATM0348674). We would like to thank Tom Jobson at Washington State University for the hydrocarbon data, Robert Griffin at Rice University and Crystal Reed and Don Collins at Texas A\&M University for the aerosol data.

Edited by: I. Trebs

\section{References}

Acker, K., Febo, A., Trick, S., Perrino, C., Bruno, P., Wiesen, P., Möller, D., Wieprecht, W., Auel, R., Giusto, M., Geyer, A., Platt, U., and Allegrini, I.: Nitrous acid in the urban area of Rome, Atmos. Environ., 40, 3123-3133, doi:10.1016/j.atmosenv.2006.01.028, 2006a. 
Acker, K., Möller, D., Wieprecht, W., Meixner, F., Bohn, B., Gilge, S., Plass-Dülmer, C., and Berresheim, H.: Strong daytime production of $\mathrm{OH}$ from $\mathrm{HNO}_{2}$ at a rural mountain site, Geophys. Res. Lett., 33, L02809, doi:10.1029/2005GL024643, 2006b.

Amedro, D., Parker, A., Schoemaecker, C., and Fittschen, C.: Direct observation of $\mathrm{OH}$ radicals after $565 \mathrm{~nm}$ multi-photon excitation of $\mathrm{NO}_{2}$ in the presence of $\mathrm{H}_{2} \mathrm{O}$, Chem. Phys. Lett., 513, 12-16, doi:10.1016/j.cplett.2011.07.062, 2011.

Ammar, R., Monge, M., George, C., and D'Anna, B.: Photoenhanced $\mathrm{NO}_{2}$ loss on simulated urban grime, Chem. Phys. Chem., 11, 3956-3961, doi:10.1002/cphc.201000540, 2010.

Aumont, B., Chervier, F., and Laval, S.: Contribution of HONO sources to the $\mathrm{NO}_{\mathrm{x}} / \mathrm{HO}_{\mathrm{x}} / \mathrm{O}_{3}$ chemistry in the polluted boundary layer, Atmos. Environ., 37, 487-498, 2003.

Beine, H.., Dominé, F., Simpson, W., Honrath, R., Sparapani, R., Zhou, X., and King, M.: Snow-pile and chamber experiments during the Polar Sunrise Experiment "Alert 2000": exploration of nitrogen chemistry, Atmos. Environ., 36, 2707-2719, doi:10.1016/S1352-2310(02)00120-6, 2002.

Bejan, I., Abd El Aal, Y., Barnes, I., Benter, T., Bohn, B., Wiesen, P., and Kleffmann, J.: The photolysis of ortho-nitrophenols: a new gas phase source of HONO, Phys. Chem. Chem. Phys., 8, 20282035, doi:10.1039/b516590c, 2006.

Berkowicz, R., Winther, M., and Ketzel, M.: Traffic pollution modeling and emission data, Environ. Modell. Softw., 21, 454-460, 2006.

Brigante, M., Cazoir, D., D’Anna, B., George, C., and Donaldson, D.: Photoenhanced uptake of $\mathrm{NO}_{2}$ by pyrene solid films, J. Phys. Chem. A, 112, 9503-9508, doi:10.1021/jp802324g, 2008.

Businger, J., Wyngaard, J., Izumi, Y., and Bradley, E.: Flux-profile relationships in atmospheric surface layer, J. Atmos. Sci., 28, 181-189, 1971.

Carr, S., Heard, D., and Blitz, M.: Comment on "Atmospheric hydroxyl radical production from electronically excited $\mathrm{NO}_{2}$ and $\mathrm{H}_{2} \mathrm{O}$ ”, Science, 324, 5925, doi:10.1126/science.1166669, 2009.

Constant, P., Poissant, L., and Villemur, R., Annual hydrogen, carbon monoxide and carbon dioxide concentrations and surface to air exchanges in a rural area, Atmos. Environ., 42, 5090-5100, 2008.

Czader, B. H., Rappenglück, B., Percell, P., Byun, D. W., Ngan, F., and Kim, S.: Modeling nitrous acid and its impact on ozone and hydroxyl radical during the Texas Air Quality Study 2006, Atmos. Chem. Phys., 12, 6939-6951, doi:10.5194/acp-12-69392012, 2012.

Dibb, J., Arsenault, M., Peterson, M., and Honrath, R.: Fast nitrogen oxide photochemistry in Summit, Greenland snow, Atmos. Environ., 36, 2501-2511, doi:10.1016/S1352-2310(02)00130-9, 2002.

Elshorbany, Y. F., Kurtenbach, R., Wiesen, P., Lissi, E., Rubio, M., Villena, G., Gramsch, E., Rickard, A. R., Pilling, M. J., and Kleffmann, J.: Oxidation capacity of the city air of Santiago, Chile, Atmos. Chem. Phys., 9, 2257-2273, doi:10.5194/acp-92257-2009, 2009.

Fuchs, N. and Sutugin, A.: Highly dispersed aerosols, Ann Arbor Science, Ann Arbor, MI, USA, 1-90, 1971.

George, C., Strekowski, R., Kleffmann, J., Stemmler, K., and Ammann, M.: Photoenhanced uptake of gaseous $\mathrm{NO}_{2}$ on solidorganic compounds: a photochemical source of HONO?, Faraday Discuss., 130, 195-210, doi:10.1039/b417888m, 2005.
Geyer, A. and Stutz, J.: Vertical profiles of $\mathrm{NO}_{3}, \mathrm{~N}_{2} \mathrm{O}_{5}, \mathrm{O}_{3}$, and $\mathrm{NO}_{\mathrm{x}}$ in the nocturnal boundary layer: 2. Model studies on the altitude dependence of composition and chemistry, J. Geophys. Res., 109, D12307, doi:10.1029/2003JD004211, 2004.

Gonçalves, M., Dabdub, D., Chang, W., Jorba, O., and Baldasano, J.: Impact of HONO sources on the performance of mesoscale air quality models, Atmos. Environ., 54, 168-176, doi:10.1016/j.atmosenv.2012.02.079, 2012.

Häseler, R., Brauers, T., Holland, F., and Wahner, A.: Development and application of a new mobile LOPAP instrument for the measurement of HONO altitude profiles in the planetary boundary layer, Atmos. Meas. Tech. Discuss., 2, 2027-2054, doi:10.5194/amtd-2-2027-2009, 2009.

He, Y., Zhou, X., Hou, J., Gao, H., and Bertman, S.: Importance of dew in controlling the air-surface exchange of HONO in rural forested environments, Geophys. Res. Lett., 33, L02813, doi:10.1029/2005GL024348, 2006.

Horváth, L., Nagy, Z., and Weidinger, T., Estimation of dry deposition velocities of nitric oxide, sulfur dioxide, and ozone by the gradient method above short vegetation during the tract campaign, Atmos. Environ., 32, 1317-1322, 1998.

Kleffmann, J.: Daytime sources of nitrous acid (HONO) in the atmospheric boundary layer, Chem. Phys. Chem., 8, 1137-1144, doi:10.1002/cphc.200700016, 2007.

Kleffmann, J., Gavriloaiei, T., Hofzumahaus, A., Holland, F., Koppmann, R., Rupp, L., Schlosser, E., Siese, M., and Wahner, A.: Daytime formation of nitrous acid: A major source of $\mathrm{OH}$ radicals in a forest, Geophys. Res. Lett., 32, L05818, doi:10.1029/2005GL022524, 2005.

Kurtenbach, R., Becker, K., Gomes, J., Kleffmann, J., Lörzer, J., Spittler, M., Wiesen, P., Ackermann, R., Geyer, A., and Platt, U.: Investigations of emissions and heterogeneous formation of HONO in a road traffic tunnel, Atmos. Environ., 35, 3385-3394, 2001.

Kurtenbach, R., Ackermann, R., Becker, K., Geyer, A., Gomes, J., Lörzer, J., Platt, U., and Wiesen, P.: Verification of the contribution of vehicular traffic to the total NMVOC emissions in Germany and the importance of the $\mathrm{NO}_{3}$ chemistry in the city air, J. Atmos. Chem., 42, 395-411, 2002.

Landgraf, J. and Crutzen, P.: An efficient method for online calculations of photolysis and heating rates, J. Atmos. Sci., 55, 863-878, 1998.

Li, S., Matthews, J., and Sinha, A.: Atmospheric hydroxyl radical production from electronically excited $\mathrm{NO}_{2}$ and $\mathrm{H}_{2} \mathrm{O}$, Science, 319, 1657-1660, doi:10.1126/science.1151443, 2008.

Mao, J., Ren, X., Chen, S., Brune, W., Chen, Z., Martinez, M., Harder, H., Lefer, B., Rappenglück, B., Flynn, J., and Leuchner, M.: Atmospheric oxidation capacity in the summer of Houston 2006: Comparison with summer measurements in other metropolitan studies, Atmos. Environ., 44, 4107-4115, doi:10.1016/j.atmosenv.2009.01.013, 2010.

Marr, L., Black, D., and Harley, R.: Formation of photochemical air pollution in central California 1. Development of a revised motor vehicle emission inventory, J. Geophys. Res., 107, 4047, 2002.

Platt, U., Perner, D., Harris, G., Winer, A., and Pitts, J.: Observations of nitrous acid in an urban atmosphere by differential optical absorption, Nature, 285, 312-314, doi:10.1038/285312a0, 1980. 
Ren, X., Gao, H., Zhou, X., Crounse, J. D., Wennberg, P. O., Browne, E. C., LaFranchi, B. W., Cohen, R. C., McKay, M., Goldstein, A. H., and Mao, J.: Measurement of atmospheric nitrous acid at Bodgett Forest during BEARPEX2007, Atmos. Chem. Phys., 10, 6283-6294, doi:10.5194/acp-10-6283-2010, 2010.

Ren, X., Sanders, J. E., Rajendran, A., Weber, R. J., Goldstein, A. H., Pusede, S. E., Browne, E. C., Min, K.-E., and Cohen, R. C.: A relaxed eddy accumulation system for measuring vertical fluxes of nitrous acid, Atmos. Meas. Tech., 4, 2093-2103, doi:10.5194/amt-4-2093-2011, 2011.

Sarwar, G., Roselle, S., Mathur, R., Appel, W., Dennis, R., and Vogel, B.: A comparison of CMAQ HONO predictions with observations from the Northeast Oxidant and Particle Study, Atmos. Environ., 42, 5760-5770, doi:10.1016/j.atmosenv.2007.12.065, 2008.

Sarwar, G., Pinder, R., Appel, K., Mathur, R., and Carlton, A.: Examination of the impact of photoexcited $\mathrm{NO}_{2}$ chemistry on regional air quality, Atmos. Environ., 43, 6383-6387, doi:10.1016/j.atmosenv.2009.09.012, 2009.

Sörgel, M., Regelin, E., Bozem, H., Diesch, J.-M., Drewnick, F., Fischer, H., Harder, H., Held, A., Hosaynali-Beygi, Z., Martinez, M., and Zetzsch, C.: Quantification of the unknown HONO daytime source and its relation to $\mathrm{NO}_{2}$, Atmos. Chem. Phys., 11, 10433-10447, doi:10.5194/acp-11-10433-2011, 2011a.

Sörgel, M., Trebs, I., Serafimovich, A., Moravek, A., Held, A., and Zetzsch, C.: Simultaneous HONO measurements in and above a forest canopy: influence of turbulent exchange on mixing ratio differences, Atmos. Chem. Phys., 11, 841-855, doi:10.5194/acp11-841-2011, 2011b.

Stark, H., Brown, S., Wong, K., Stutz, J., Elvidge, C., Pollack, I., Ryerson, T., Dube, W., Wagner, N., and Parrish, D.: City lights and urban air, Nat. Geosci., 4, 730-731, doi:10.1038/ngeo1300, 2011.

Stemmler, K., Ammann, M., Donders, C., Kleffmann, J., and George, C.: Photosensitized reduction of nitrogen dioxide on humic acid as a source of nitrous acid, Nature, 440, 195-198, doi:10.1038/nature04603, 2006.

Stemmler, K., Ndour, M., Elshorbany, Y., Kleffmann, J., D’Anna, B., George, C., Bohn, B., and Ammann, M.: Light induced conversion of nitrogen dioxide into nitrous acid on submicron humic acid aerosol, Atmos. Chem. Phys., 7, 4237-4248, doi:10.5194/acp-7-4237-2007, 2007.

Stockwell, W., Kirchner, F., Kuhn, M., and Seefeld, S.: A new mechanism for regional atmospheric chemistry modeling, J. Geophys. Res., 102, 25847-25879, 1997.

Stull, R.: An introduction to boundary layer meteorology, Kluwer Academic Publishers, Dodrecht/Boston/London, 1-666, 1988.

Su, H., Cheng, Y., Shao, M., Gao, D., Yu, Z., Zeng, L., Slanina, J., Zhang, Y., and Wiedensohler, A.: Nitrous acid (HONO) and its daytime sources at a rural site during the 2004 PRIDE-PRD experiment in China, J. Geophys. Res.-Atmos., 113, D14312, doi:10.1029/2007JD009060, 2008.

Su, H., Cheng, Y., Oswald, R., Behrendt, T., Trebs, I., Meixner, F., Andreae, M., Cheng, P., Zhang, Y., and Pöschl, U.: Soil nitrite as a source of atmospheric HONO and $\mathrm{OH}$ radicals., Science, 333, 1616-1618, doi:10.1126/science.1207687, 2011.
Trick, S.: Formation of nitrous acid on urban surfaces - a physicalchemical perspective, Ph.D. thesis, University of Heidelberg, Heidelberg, Germany, 2004.

Villena, G., Kleffmann, J., Kurtenbach, R., Wiesen, P., Lissi, E., Rubio, M., Croxatto, G., and Rappenglück, B.: Vertical gradients of $\mathrm{HONO}, \mathrm{NO}_{\mathrm{x}}$ and $\mathrm{O}_{3}$ in Santiago de Chile, Atmos. Environ., 45, 3867-3873, doi:10.1016/j.atmosenv.2011.01.073, 2011.

Vogel, B., Vogel, H., Kleffmann, J., and Kurtenbach, R.: Measured and simulated vertical profiles of nitrous acid-Part II. Model simulations and indications for a photolytic source, Atmos. Environ., 37, 2957-2966, 2003.

Wong, K. and Stutz, J.: Influence of nocturnal vertical stability on daytime chemistry: A one-dimensional model study, Atmos. Environ., 44, 3753-3760, doi:10.1016/j.atmosenv.2010.06.057, 2010.

Wong, K. W., Oh, H.-J., Lefer, B. L., Rappenglück, B., and Stutz, J.: Vertical profiles of nitrous acid in the nocturnal urban atmosphere of Houston, TX, Atmos. Chem. Phys., 11, 3595-3609, doi:10.5194/acp-11-3595-2011, 2011.

Wong, K. W., Tsai, C., Lefer, B., Haman, C., Grossberg, N., Brune, W. H., Ren, X., Luke, W., and Stutz, J.: Daytime HONO vertical gradients during SHARP 2009 in Houston, TX, Atmos. Chem. Phys., 12, 635-652, doi:10.5194/acp-12-635-2012, 2012.

Woodill, L. A. and Hinrichs, R.: Heterogeneous reactions of surface-adsorbed catechol with nitrogen dioxide: substrate effects for tropospheric aerosol surrogates., Phys. Chem. Chem. Phys., 12, 10766-10774, doi:10.1039/c002079f, 2010.

Zhang, N., Zhou, X., Shepson, P., Gao, H., Alaghmand, M., and Stirm, B.: Aircraft measurement of HONO vertical profiles over a forested region, Geophys. Res. Lett., 36, L15820, doi:10.1029/2009GL038999, 2009.

Zhou, X., Beine, H., Honrath, R., Fuentes, J., Simpson, W., Shepson, P., and Bottenheim, J.: Snowpack photochemical production of HONO: a major source of $\mathrm{OH}$ in the Arctic boundary layer in springtime, Geophys. Res. Lett., 28, 4087-4090, doi:10.1029/2001GL013531, 2001.

Zhou, X., He, Y., Huang, G., Thornberry, T., Carroll, M., and Bertman, S.: Photochemical production of nitrous acid on glass sample manifold surface, Geophys. Res. Lett., 29, 4590, doi:10.1029/2002GL015080, 2002.

Zhou, X., Gao, H., He, Y., Huang, G., Bertman, S., Civerolo, K., and Schwab, J.: Nitric acid photolysis on surfaces in low- $\mathrm{NO}_{\mathrm{X}}$ environments: Significant atmospheric implications, Geophys. Res. Lett., 30, 2217, doi:10.1029/2003GL018620, 2003.

Zhou, X., Huang, G., Civerolo, K., Roychowdhury, U., and Demerjian, K.: Summertime observations of $\mathrm{HONO}, \mathrm{HCHO}$, and $\mathrm{O}_{3}$ at the summit of Whiteface Mountain, New York, J. Geophys. Res.-Atmos., 112, D08311, doi:10.1029/2006JD007256, 2007.

Zhou, X., Zhang, N., TerAvest, M., Tang, D., Hou, J., Bertman, S., Alaghmand, M., Shepson, P., Carroll, M., Griffith, S., Dusanter, S., and Stevens, P.: Nitric acid photolysis on forest canopy surface as a source for tropospheric nitrous acid, Nat. Geosci., 4, 440-443, doi:10.1038/NGEO1164, 2011. 